\title{
What Do We Know About Corporate Headquarters? A Review, Integration, and Research Agenda
}

\section{Citation}

Menz, Markus, Sven Kunisch, and David J. Collis. "What Do We Know About Corporate Headquarters? A Review, Integration, and Research Agenda." Harvard Business School Working Paper, No. 14-016, August 2013

\section{Permanent link}

http://nrs.harvard.edu/urn-3:HUL.InstRepos:11508210

\section{Terms of Use}

This article was downloaded from Harvard University's DASH repository, and is made available under the terms and conditions applicable to Open Access Policy Articles, as set forth at http:// nrs.harvard.edu/urn-3:HUL.InstRepos:dash.current.terms-of-use\#OAP

\section{Share Your Story}

The Harvard community has made this article openly available.

Please share how this access benefits you. Submit a story.

Accessibility 
H A R VARD D B U S I N E S S S C H O O L

What Do We Know About Corporate Headquarters?

\title{
A Review, Integration, and Research Agenda
}

\author{
Markus Menz \\ Sven Kunisch \\ David J. Collis
}

\section{Working Paper}

14-016

August 19, 2013 


\title{
WHAT DO WE KNOW ABOUT CORPORATE HEADQUARTERS? A REVIEW, INTEGRATION, AND RESEARCH AGENDA*
}

\author{
Markus Menz \\ Institute of Management, University of St. Gallen \\ Dufourstrasse 40a, 9000 St. Gallen, Switzerland \\ 41712247612 \\ markus.menz@unisg.ch \\ Sven Kunisch \\ Institute of Management, University of St. Gallen \\ Dufourstrasse 40a, 9000 St. Gallen, Switzerland \\ 41712247622 \\ sven.kunisch@unisg.ch \\ David J. Collis \\ Harvard Business School \\ Soldiers Field, Boston, MA 02163, U.S.A. \\ 16174956768 \\ dcollis@hbs.edu \\ Working Paper \\ Version: August 19, 2013
}

\begin{abstract}
During the past five decades, scholars have studied the corporate headquarters (CHQ) - the multidivisional firm's central organizational unit. The purpose of this article is to review the diverse and fragmented literature on the CHQ and to identify the variables of interest, the dominant relationships, and the contributions. We integrate, for the first time, the existing knowledge of the CHQ into an organizing framework. Based on a synthesis of the literature, we identify major shortcomings and gaps, and present an agenda for future research that contributes to our understanding of the CHQ and the multidivisional firm.
\end{abstract}

\section{Keywords}

Corporate headquarters, corporate parent, corporate center, corporate strategy, multidivisional firm, multibusiness firm, multinational corporation.

* Copyright @ 2013 by Markus Menz, Sven Kunisch, and David J. Collis. The authors gratefully acknowledge Andrew Campbell, Steven W. Floyd, Günter Müller-Stewens, and Torsten Schmid for insightful discussions and helpful comments on earlier versions of this paper. The usual disclaimer applies. 
Since Chandler's (1962) seminal work five decades ago, research on the multidivisional firm has developed into one of the most important areas of management research. While the majority of this research deals with the firm's portfolio of businesses and international subsidiaries, there is a smaller but significant body of literature on the corporate headquarters (CHQ) - the multidivisional firm's central organizational unit. This research focuses on the CHQ's roles and activities (e.g., Chandler, 1991; Foss, 1997), integrating mechanisms (e.g., Goold \& Campbell, 1987; Semadeni \& Cannella Jr., 2011), resources and capabilities (e.g., Adner \& Helfat, 2003; Song, 2002; Tan \& Vertinsky, 1996), structure (design and staffing) (e.g., Collis, Young \& Goold, 2007, 2012; Kleinbaum \& Stuart, 2013), location (e.g., Birkinshaw, Braunerhjelm, Holm \& Terjesen, 2006; Laamanen, Simula \& Torstila, 2012), and its relationships with the firm's operating units (e.g., Bouquet \& Birkinshaw, 2008; Joseph \& Ocasio, 2012; Nell \& Ambos, 2013). There is consensus among scholars that the CHQ is critical to achieve a corporate advantage and, thus, to economically justify the existence of the multidivisional firm (Collis \& Montgomery, 1998), which is the dominant form of modern economic organizations accounting for about 60 percent of output in the US (Villalonga, 2004). However, since scholars have studied CHQ phenomena from diverse perspectives and have employed different methods, there is a need for a framework that integrates this research in order to advance theory on the multidivisional firm.

Specifically, three factors motivated this synthesis of research on the CHQ. First, while there is a substantial amount of research on the CHQ, the insights from these works are diffuse, requiring consolidation to take stock of this body of knowledge. By delineating the evolution of this literature and the different perspectives, we identify the state of CHQ research and enhance our understanding of how research issues have emerged. We also provide an overview of the 
most frequently explored CHQ phenomena and establish a common vocabulary. Second, research on the CHQ is increasingly disconnected, having developed along four different tracks in the economic, organization, international business, and practice-oriented traditions. This has not only led to different research foci and approaches to studying the CHQ, but also to a lack of understanding of the variables of interest and the relationships between them. An important purpose of the review is thus to provide a first comprehensive framework of CHQ research that integrates the dispersed insights, identifies the most relevant variables of interest, and specifies

the dominant relationships between them. Third, while our review reveals the contributions of the literature on the CHQ, it also uncovers several weak, and even unexplored research areas. In addition, the integrative review reveals a potential for cross-fertilization, for example, between the academic and practice-oriented literatures. We therefore identify gaps within and across the different research areas and highlight pressing future research questions that will help advance our understanding of the CHQ and the multidivisional firm.

The remainder of this paper is organized as follows. First, we briefly present the evolution of CHQ research with its different theoretical traditions and sub-streams. Second, we review the prior studies and integrate them into an organizing framework. Finally, based on a synthesis of the literature, we propose a comprehensive future research agenda.

\section{EVOLUTION AND TRADITIONS OF CHQ RESEARCH}

Although its roots can be traced backed to the 1920s (Knight, 1921; Unknown, 1929), Chandler's (1962) seminal book Strategy and Structure: Chapters in the History of the American Industrial Enterprise triggered research on the CHQ. Since then, CHQ research has evolved along four - somewhat separate - tracks, each characterized by distinct research traditions, distinct phenomena, and different methods (see Table 1). 


\section{Insert Table 1 about here}

First, particularly early CHQ studies focused on the role of the CHQ in the multibusiness firm from an economic perspective. Research in the economic tradition focuses on the role and governance style of the CHQ as well as on its relationship with the firm's operating units and is both conceptual (including formal modeling) and empirical with quantitative analyses of largescale data. These studies built on transaction cost theory (Coase, 1937; Williamson, 1975, 1981), agency theory (Berle \& Means, 1932; Jensen \& Meckling, 1976), and the efficient market hypothesis (Fama, 1970), which is a pillar of financial economics (Markovitz, 1952; Modigliani \& Miller, 1958). For example, according to agency theory, the CHQ of a multibusiness firm delegates decision-making rights to the firm's businesses, and the role of corporate management is to minimize agency costs by, for example, appropriately exercising control (Eisenhardt, 1985).

Second, a major strand of research on the CHQ draws on organizational perspectives. During the 1960s and 1970s, Chandler's work influenced many of the early studies, which largely originated from Harvard Business School (e.g., Berg, 1969; Berg, 1977; Chandler, 1962; Lorsch \& Allen, 1973; Pitts, 1976, 1977) and focused on the organization design of the multibusiness firm and the unique functions of the CHQ. Diverse organization theories, particularly the resource-based perspectives, which include the resource-based view (Barney, 1991; Peteraf, 1993; Wernerfelt, 1984), the knowledge-based view (Grant, 1996; Nonaka, 1994; Spender, 1996), and, more recently, the dynamic capabilities view (Eisenhardt \& Martin, 2000; Teece, Pisano \& Shuen, 1997) informed CHQ research. Perhaps most notably, CHQ research in this tradition follows a contingency argument (e.g., Chandler, 1962; Chandler, 1991; Hill, Hitt \& Hoskisson, 1992) to offer explanations for the diverse CHQ roles and activities and their suitability for different corporate strategies (Collis et al., 2007; Hill \& Hoskisson, 1987). 
Third, in parallel - and particularly over the past two decades -, we have observed extensive CHQ research from a practice-oriented perspective. These studies are often conceptual and offer detailed case illustrations on the role, activities, and design of the CHQ. As they are more concerned with giving normative advice, they usually do not draw on an explicit theoretical lens. Scholars with a European background have largely influenced this strand of the literature, notably scholars from the Ashridge Strategic Management Centre, who introduced the notion of "parenting theory" to stress the CHQ's value-adding role in the multidivisional firm (e.g., Alexander, 1992; Goold \& Campbell, 1987; Goold, Campbell \& Alexander, 1994).

Fourth, another strand of research on the CHQ draws on international business perspectives. This research focuses on CHQ phenomena specific to the multinational corporation (MNC), such as the relationships between the CHQ and the firm's subsidiaries (Bouquet \& Birkinshaw, 2008; Ciabuschi, Forsgren \& Martín, 2011b; Nell \& Ambos, 2013) and the CHQ's geographic (re-)location (Baaij, Mom, Van Den Bosch \& Volberda, 2012; Birkinshaw et al., 2006; Laamanen et al., 2012). These international business topics, often studied incorporating a subsidiary rather than a CHQ perspective, may have led research on the CHQ in the MNC to evolve separately from research on the CHQ in the multibusiness firm.

In light of the literature's evolution and the different research tracks, it is no surprise that a variety of terms and definitions has emerged to describe the CHQ (for an overview of selected CHQ terms and definitions, see Appendix 1). Despite this variety, however, there seems to be a common, if yet unarticulated, understanding of what the CHQ is. We thus define the CHQ as the firm's central organizational unit, (structurally) separated from the operating units (business and geographic units), hosting corporate executives and staff, as well as central staff functions that fulfil various roles for the overall firm. 


\section{REVIEW OF CHQ RESEARCH AND ORGANIZING FRAMEWORK}

To provide a complete and coherent picture of the existing knowledge on the CHQ, we followed a structured approach that included multiple techniques to search for relevant literature (Short, 2009; Webster \& Watson, 2002). First, using the EBSCO database, we searched the titles, keywords, and abstracts of leading academic and practice-oriented management journals' articles published between Chandler's (1962) publication and the end of 2012 for the term corporate headquarter(s), as well as for common related terms: central administrative office, corporate center/centre, central office, corporate parent, parent company, parent firm, and corporate level. Second, we manually screened the identified articles and excluded those that did not relate to the study of the CHQ. Third, based on a backward and forward search, as well as a screening of forthcoming publications, we identified additional articles for the review. We also considered other influential publications, such as important books, as they provide background information and point to promising future research avenues. This process led to a total of 98 publications (for an overview on the search process and results, see Appendix 2).

Building on the analysis of the existing literature, we integrated the studies' themes into an organizing framework. As illustrated in Figure 1, the existing studies inform our knowledge about the characteristics of the CHQ (1), the CHQ's relationships with the firm's operating units (2-1), the effect of firm characteristics (3-1) and environmental factors (4-1) on the CHQ, as well

as the CHQ's impact on intermediate (1-5) and performance outcomes (1-6). Appendix 3 provides the studies' key findings. Together with the organizing framework, it enables an overview of the scholars' accomplishments and helps reveal promising future research areas.

Insert Figure 1 about here 


\section{Research on CHQ Characteristics (1)}

At the core of the literature is research on the characteristics of the CHQ. This research can be categorized into studies on the CHQs' roles and activities, integrating mechanisms, resources and capabilities, structure (staffing and design), and location.

Roles and activities. The most frequent topic of the research is on the CHQ's roles and individual activities. Chandler (1962) originally identifies three "duties" of the multidivisional firm's CHQ: coordinating and integrating the output of the businesses, providing centralized and specialized shared services, and allocating future use and the appraisal of the present performance of resources. Since then, various descriptions of the CHQ roles have evolved (Balderston, 1962; Collis \& Montgomery, 1997; Collis et al., 2007; Foss, 1997; Goold, Pettifer \& Young, 2001; Hungenberg, 1993; Kono, 1999; Pettifer, 1998), which can be summarized into three major roles: (1) performing obligatory (public) company functions, also referred to as minimum CHQ; (2) providing centralized services to the firm's operating units, such as centralized HR, IT, or marketing services; and (3) value creation, "functions governing the development, allocation, and deployment of valuable corporate resources within the hierarchy" (Collis et al., 2007: 388).

While the first two roles are "administrative" (Chandler, 1991) or "loss-preventive" (Foss, 1997; Markides, 2002), the third role is "entrepreneurial" (Chandler, 1962, 1991; Foss, 1997) and supposed to lead to a corporate advantage (Collis \& Montgomery, 1998). Not surprisingly, numerous studies have examined individual, potentially value-adding, activities of the CHQ, such as the utilization of coinsurance effects (Berger \& Ofek, 1995), organization (re-)design (Goold \& Campbell, 2002a; Hoskisson, 1987; Howard, 1991), corporate initiatives (Darragh \& Campbell, 2001), investment decision-making (Barton, Brown, Cound, Marsh \& 
Willey, 1992; MacMillan \& Meshulach, 1983), transfer of labor policies (Summers, 1965), and risk management (Miller \& Waller, 2003). In this vein, particularly notable is the substantial amount of research on CHQ's (corporate) strategic planning activities (Campbell, 1999; Greenwood, 1964; Kaplan \& Norton, 2005; Leontiades \& Tezel, 1981; Murdick, 1964; Stubbart, 1982). Although these early studies suggest that corporate planning and strategizing is one of the key CHQ responsibilities, subsequent academic CHQ research largely neglected this topic.

Integrating mechanisms. Scholars have focused on a set of CHQ characteristics that can be summarized as the CHQ's integrating mechanisms to run the overall firm. This research deals with the extent and type of control and monitoring exercised by the CHQ (Balderston, 1962; Chandler, 1991; Chen, Park \& Newburry, 2009; Crilly, 2011; Goold \& Campbell, 1987; Govindarajan, 1988; Greenwood, Hinings \& Brown, 1990; Hill et al., 1992; Jacque \& Vaaler, 2001; Roth \& Nigh, 1992; Semadeni \& Cannella Jr., 2011), the extent of CHQ's planning influence (Berg, 1969; Goold \& Campbell, 1987), and, to a lesser extent, with the CHQ's budgeting (Govindarajan, 1988), and influence over specific operating units' decisions (Martinez \& Ricks, 1989). Informed by agency-theoretic foundations, there has particularly accumulated a thorough understanding of the CHQ's control mechanisms in both multibusiness and multinational firms, including the recognition of different control types and dimensions and their suitability for different firms. Greenwood and colleagues (1990), for example, distinguish three control dimensions in their study of the CHQ in professional partnerships: strategic, marketfinancial, and operating control. Nevertheless, important questions in this area are still unexplored, particularly in the context of the $\mathrm{MNC}$, as recent contributions demonstrate. Chen and colleagues (2009), for example, analyze a survey of 201 large manufacturing joint ventures 
in China and find that the application of three CHQ control types, output, process, and social control, is influenced by the CHQ's resource contributions.

Building upon different CHQ integrating mechanisms, such as control and planning, scholars have developed conceptual frameworks that enhance our understanding of the role of the CHQ in governing and managing the multidivisional firm (Berg, 1969; Chandler, 1991; Goold \& Campbell, 1987). Among the most prominent contributions is Goold and Campbell's (1987) notion of strategic management styles, later known as "parenting styles" (Goold et al., 1994). Building upon findings from a field study of 16 large UK firms, they distinguish the extent of control influence and strategic planning influence as the CHQ's two central integrating mechanisms and identify eight different management styles. They also find that firms most frequently apply the strategic planning, strategic control, and financial control styles. However, none of these three styles is superior, rather, their benefits depend on the firm's context.

Resources and capabilities. Representing a smaller strand of the literature on CHQ characteristics, scholars have studied the nature and impact of the CHQ's resources and capabilities (Alexander, 1992; Batten, 2002; Campbell, 1995; Campbell, Goold \& Alexander, 1995b; Collis \& Montgomery, 1997; Foss, 1997; Goold, 1996a; Hanan, 1969; Song, 2002). As one would expect, this literature draws implicitly or explicitly on the resource-based view of firm and specifies its main assumptions for the CHQ. It is particularly characterized by an emphasis on conceptual frameworks and on illustrative case examples. For example, Campbell and colleagues (1995b) propose a framework that emphasizes the capabilities and resources of the CHQ and their impact on the businesses. To add value, not only must opportunities for performance improvements of the businesses exist, but the CHQ must also possess special capabilities and resources, and it must understand the critical success factors of the businesses. 
Further, Alexander (1992) suggests that the potential scope of the CHQ roles should be determined by considering its particular capabilities. This literature has culminated in more academic-oriented studies on the CHQ's competencies (Hitt \& Ireland, 1986; Hitt \& Ireland, 1987; Markides, 2006; Markides \& Williamson, 1994, 1996; Yavitz \& Newman, 1982). Hitt and Ireland (1986), for instance, find with a survey of 185 US industrial firms that "a need also exists for distinctive competencies at the corporate level” (p. 402).

More recently, several scholars have started to address the question of how the CHQ may contribute to a multidivisional firm's competitive advantage by developing dynamic capabilities (e.g., Adner \& Helfat, 2003; Bowman \& Ambrosini, 2003). Adner and Helfat (2003), for example, introduce the term "dynamic managerial capabilities", defined as "the capabilities with which managers build, integrate, and reconfigure organizational resources and competencies" (p. 1012). Based on a longitudinal study of 30 US firms in the petroleum industry from 1977 to 1997, they find that differences in the managerial decisions in the CHQ are partly responsible for performance differences across firms. Although the previous studies' cumulative findings from a resource-based perspective have offered valuable insights, this literature is still relatively small and sometimes provides rather broad suggestions of how the CHQ functions and adds value.

Structure. Drawing on knowledge of the CHQ's roles, integrating mechanisms, and resources, prior research has derived implications for its structure. First, scholars focus on the implications of particular roles of the CHQ for its size and staffing (Collis \& Montgomery, 1998; Collis et al., 2007, 2012; Goold et al., 2001; Kono, 1999; Stalk Jr., 2005; Young, 1998a). The findings of prior research consistently reveal that the justification for the presence of certain CHQ staff and, thus, the size of the CHQ depends on the CHQ roles, and, thereby, on the firm's strategy. Based on a survey with an international sample of 467 firms, Collis and colleagues 
(2007), for example, distinguish in one of the few academic studies on this topic between "obligatory" and "discretionary" staff and find that particularly the latter depends on the number and types of value creating activities performed at the CHQ. Hence, while there is some knowledge on the CHQ's structural features, we know little about the processes within the CHQ. Interestingly, scholars have more recently started to study the specifics of CHQ staff and executives (Kleinbaum \& Stuart, 2013; Stalk Jr., 2005). Drawing upon network theory, Kleinbaum and Stuart (2013), for example, find based on an email analysis of CHQ staff that their networks are larger, more integrative, and richer in structural holes.

In addition, there are several normative suggestions on how to effectively design the CHQ, primarily in a practice-oriented literature (Campbell, Kunisch \& Müller-Stewens, 2012; Hanan, 1969; Thurm, 2005; Young, 1993b). Interestingly, scholars have recently also begun to study the CHQ's functional units, so called corporate functions (Campbell et al., 2012). To a lesser extent, the research reviewed here also deals with the CHQ's redesign and transformation, (Bazzaz \& Grinyer, 1981; Ferlie \& Pettigrew, 1996; Goold et al., 2001; Stubbart, 1982). For example, Bazzaz and Grinyer (1981) find based on an analysis of 48 interviews with corporate planners in UK firms that the CHQ's planning subunit had increased in its size and scope since the late 1960s. Ferlie and Pettigrew (1996) more generally identified CHQ change as an increasingly important phenomenon of the late 1980s and early 1990s.

Location. Scholars have also explored the CHQ's location as a unique characteristic of this central unit. The majority of the research on the CHQ in the MNC considers the location of the CHQ (implicitly) as the respective study's context (Chen et al., 2009; Law, Song, Wong \& Chen, 2009; Martinez \& Ricks, 1989; Summers, 1965). Otherwise, scholars have recently started to focus explicitly on the (re-)location of the CHQ as the major theme in their studies (Baaij et 
al., 2012; Birkinshaw et al., 2006; Laamanen et al., 2012). The few studies predominantly examine the extent to which factors in the firm's internal and external contexts affect the (re-) location of the CHQ. Laamanen and colleagues (2012) recently find that high taxes and a high employment rate increase the likelihood of relocation, whereas central location and low taxes increase the attractiveness of the CHQ location. Particularly the research on CHQ relocations in the MNC, for example, Birkinshaw and colleagues' (2006) study of Swedish firms, may further substantiate the finding that $\mathrm{CHQ}$ is not a stable entity, but that it transforms over time to meet internal and external demands.

\section{The CHQ and the Operating Units' Characteristics (2-1)}

The majority of prior CHQ research considers the characteristics of the firm's operating units and their influence on/relationship with the CHQ. Although the cumulative findings indicate that this research is in an advanced stage, it has emerged in two largely separate camps, either focusing on a firm's business units or on its international subsidiaries.

Business units. The study of how distinct characteristics of the firm's business (product) units affect the $\mathrm{CHQ} /$ their relationship with the $\mathrm{CHQ}$ has a long tradition in CHQ research. The literature has considered diverse characteristics such as the business units' needs (Campbell, Goold \& Alexander, 1995a), bargaining power towards the CEO (Scharfstein \& Stein, 2000), investment prospects (Scharfstein, 1998), maturity (Goold, 1996b), similarity of products, technologies, and customers (Young, 1998b), strategic mission and competitive strategy (Gupta, 1987), size (Russo, 1992; Semadeni \& Cannella Jr., 2011), and ownership structure (Semadeni \& Cannella Jr., 2011). In addition, there are many studies on the relatedness of the business units to each other. Since this characteristic is typically explored for the overall business portfolio and, thus, represents a firm's diversification strategy, it is reviewed in a later section. 
Studies on business unit characteristics focus either on the fit/alignment of the business units with the CHQ or on the processes in the relationship between the BU and the CHQ. In the first strand of the literature, there is consensus that the fit between the CHQ and the business units is advantageous (Balderston, 1962; Campbell et al., 1995a), and that the CHQ roles and integrating mechanisms should be aligned with the specific characteristics of the business units (Goold, 1996b; Govindarajan, 1988; Semadeni \& Cannella Jr., 2011). In one of the few recent academic studies on this topic, Semadeni and Cannella Jr. (2011) find by analyzing a sample of 142 spin-offs of listed US firm from 1986 to 1997 that "while child firms benefit from some links to the parent, having too many links is negatively related to performance" (p. 1083).

The second strand of the literature centers on the processes involved in the relationship between the CHQ and the businesses (Goold, 1996b; Joseph \& Ocasio, 2012; MacMillan \& Meshulach, 1983). For instance, Gupta (1987) finds in a survey of 58 business unit general managers of eight Fortune 500 firms that CHQ-business relations characterized by openness and subjectivity in performance assessment enhance businesses pursuing a differentiation competitive strategy, while they negatively affect businesses pursuing a cost-leadership competitive strategy. Further, Joseph and Ocasio (2012) perform an inductive study of General Electric's governance system from 1951 to 2001 and identify "collective vertical interactions between the corporate office and business units through cross-level channels" (p. 633) as an unexplored aspect of the multidivisional firm. Given the importance of CHQ-business unit relationships for a multidivisional firm's success, it is surprising that the insights on this topic are still relatively sparse.

International subsidiaries. Particularly international business research has advanced our understanding of the relationships between a firm's operating units and the CHQ. Early studies 
already highlighted that the role of the CHQ in the MNC depends on the characteristics of the international subsidiaries (Rutenberg, 1969) and that a firm's change towards multinational operations leads to changes in its CHQ reporting and control systems (McInnes, 1971). Prior research has focused on diverse characteristics of a firm's international units, including their international subsidiaries' networks and actions (Vahlne, Schweizer \& Johanson, 2012), local stakeholders (Crilly, 2011), resource dependence, importance, managers' nationality (Martinez \& Ricks, 1989), initiatives and autonomy (Ambos, Andersson \& Birkinshaw, 2010), internal and external embeddedness (Ciabuschi, Dellestrand \& Martín, 2011a; Nell \& Ambos, 2013), ownership arrangements and choices (Chan \& Makino, 2007; Martinez \& Ricks, 1989), as well as expatriate managers' decision autonomy (Takeuchi, Shay \& Li, 2008). For example, Martinez and Ricks (1989) draw upon resource-dependence and control theory and find with a survey of 115 Mexican affiliates of a US-based MNCs that the CHQ's influence is positively related to the affiliate's resource dependence. Not surprisingly, most studies in this vein implicitly or explicitly deal with the location as a characteristic of the international subsidiaries analyzed.

Common to most of the studies in this area is their focus on examining how distinct characteristics of a firm's international subsidiaries affect (processes in) CHQ-subsidiary relationships (Ambos et al., 2010; Birkinshaw \& Hood, 2001; Crilly, 2011; Foss, Foss \& Nell, 2012; Law et al., 2009; Roth \& Nigh, 1992; Takeuchi et al., 2008; Tomassen, Benito \& Lunnan, 2012; Vahlne et al., 2012). While the rich research has substantiated our knowledge on the effective design of CHQ-subsidiary relationship, it has been predominantly focused on questions of control and coordination from a CHQ perspective. For example, Roth and Nigh (1992) analyze data of a survey of 105 foreign subsidiaries and find that the coordination of primary activities and personal integrating mechanisms (i.e., behavioral control) positively affect, while 
conflict negatively affects the effectiveness of the CHQ-subsidiary relationship. Recently, however, several studies have shifted the perspective towards the subsidiary and provide novel insights into the complex processes. Exemplary is Ambos and colleagues' (2010) study of 257 foreign-owned subsidiaries in Australia, Canada, and the UK, in which they find that "subsidiaries are not able to increase their influence through initiatives unless they get headquarters' attention" (p. 1099).

Similarly, a small sub-strand of the literature deals with more complex structures, namely regional headquarters (RHQ) and their relationships with the CHQ (Alfoldi, Clegg \& McGaughey, 2012; Mahnke, Ambos, Nell \& Hobdari, 2012; Ohmae, 1989; Parks, 1974). Among the few academic contributions in this area, Mahnke and colleagues (2012) highlight the importance of the CHQ-RHQ relationship. They analyze survey data of 42 RHQ in five countries and find that the RHQ serves as a bridge between the firm's operating units and its CHQ and that the RHQ's autonomy and signaling behavior have significant effects on the RHQ's influence on the firm's corporate strategy. Although this literature has recently gained increased attention, there are still relatively few insights into those relationships.

\section{The CHQ and Firm Characteristics (3-1)}

Most studies on the CHQ implicitly or explicitly consider firm characteristics, such as the

firm's corporate governance, corporate strategy, corporate structure, and other firm characteristics, for example, firm size.

Corporate governance. Relatively few CHQ studies cover aspects of a firm's corporate governance, such as ownership, the CEO, and top management teams (TMTs). The majority of this literature analyzes the impact of various types of shareholders and ownership structure on the role and design of the CHQ (Alexander, 1992; Birkinshaw et al., 2006; Collis et al., 2007, 
2012; Ferlie \& Pettigrew, 1996; Scharfstein, 1998). Ferlie and Pettigrew (1996) suggest that particularly institutional investors might affect CHQ restructuring. Scharfstein (1998) identifies in a longitudinal study of 165 US conglomerates agency problems between investors and the $\mathrm{CHQ}$, especially in firms in which the management has a small equity stake. In a comprehensive study, Collis and colleagues (2007) argue that the governance system affects the size of the CHQ and distinguish government, public, and private ownership. Their study reveals that governmentowned firms have larger CHQs than firms with other forms of ownership, however it does not confirm that privately owned firms have smaller CHQs than public firms. In sum, the existing research provides initial evidence that ownership types and structures affect a multidivisional firm's CHQ. There is much less knowledge, however, on strategic leader's effect on the CHQ, with only two studies addressing this topic (Campbell et al., 2012; Law et al., 2009).

Corporate strategy. Among the most frequent topics in CHQ research is the corporate strategy's influence on the CHQ. Overall, there is large agreement that the CHQ's roles, integrating mechanisms, resources and capabilities, and structure need to be aligned with the firm's corporate strategy (Berg, 1969, 1977; Hill et al., 1992; Leontiades \& Tezel, 1981; Raynor \& Bower, 2001; Teece, 1982; Van Oijen \& Douma, 2000). While few studies have addressed more "exotic" topics, for example, why a CHQ's building architecture should reflect the firm's mission (Thurm, 2005), the dominant theme is the fit between a firm's diversification strategy (which is typically considered as a proxy of the corporate strategy) and the CHQ. Both detailed case studies and large-scale quantitative surveys provide strong evidence for the hypothesis that, in order to be valuable, the CHQ must generally fit with the extent of the firm's diversification (e.g., Collis et al., 2007; Hansen \& Peytz, 1991; Hill et al., 1992; Hoskisson, 1987; Hungenberg, 1993; Kono, 1999; Porter, 1987). A recent study by Collis and colleagues (2007) confirms 
previous studies' findings that a firm's corporate strategy is the most important determinant of the CHQ's role and size in a multibusiness firm.

Few studies go beyond these general findings and investigate corporate strategy's effect on specific CHQ activities (Leontiades \& Tezel, 1981; Van Oijen \& Douma, 2000). Van Oijen and Douma (2000) find that high performing multibusiness firms align certain CHQ activities (planning, evaluation, selection, motivation, and support) with the diversification strategy, however, not other activities (coordination, job rotation). Further, by surveying 88 chief planning officers, Leontiades and Tezel (1981) reveal that the planning efforts of the CHQ increase as firms diversify, which indicates that the importance of some CHQ activities depends on the diversification strategy. A major shortcoming of the literature is that it neglects differences across a firm's operating units and, thus, the complexity of a firm's corporate strategy. Raynor and Bower (2001) suggest that "diversification strategy can be a mixture of related and unrelated elements; companies can pursue varying degrees of relatedness between divisions" (p. 98), which simultaneously demands different CHQ roles. In addition, except for Collis and colleagues (2012) who find that the CHQ size is positively related to MNC's geographic scope, very few studies have explored a firm's international (diversification) strategy's effect on the CHQ.

Corporate structure. The firm's organization structure plays an important role in CHQ research. The findings of this literature relate to the alignment of the role of the CHQ with the overall organization structure and to the impact of specific novel organization designs. Since Chandler (1962) suggested that the creation of the CHQ (and of divisional headquarters (DHQ)) is contingent upon the adoption of the multidivisional (M-form) organization structure, most studies have found that aligning the structure with the corporate strategy and the CHQ is critical for superior firm performance (e.g., Collis et al., 2007; 2012; Hill et al., 1992; Hill \& Hoskisson, 
1987; Hoskisson, 1987; Markides \& Williamson, 1996). Hoskisson (1987), for example, performs a longitudinal study of 62 US industrial firms and reveals that the implementation of the M-form organization design enhances firm performance for unrelated diversifiers, while it decreases the performance for vertical integrators. Relatedly, Hill and colleagues (1992) analyze a survey of 184 Fortune 1,000 firms and find that the fit between a firm's diversification strategy, organization structure, and CHQ control systems leads to superior performance. Hence, although Hitt and Ireland (1986) find that the CHQ's effect on firm performance does not vary by type of organization structure, the majority of the studies supports a contingency perspective on the CHQ's role.

A less prominent strand of the literature has extended the study of corporate structures' impact on the CHQ by considering either novel organization designs or alternative emerging theoretical perspectives on the alignment. This includes the study of the CHQ in multiunit firms (Garvin \& Levesque, 2008), in professional partnerships (p2-form) (Greenwood et al., 1990), and in network MNCs (Foss et al., 2012). Greenwood and colleagues (1990), for example, study large US accounting firms and find that the CHQ in a professional partnership differs from that of a firm with an M-form or holding company organization design along three control dimensions. More generally, Goold and Campbell (2002b) suggest that modern organizational arrangements complicate the clear distinction between the operating units and the centralized administrative units because of an added layer of divisional headquarters. Finally, scholars also incorporate novel perspectives and analyze aspects such as the fit of distinct CHQ dynamic capabilities with Mintzberg’s (1979) design parameters (Bowman \& Ambrosini, 2003).

Other firm characteristics. Among the other firm characteristics explored in the context of CHQ research are diverse aspects, such as firm's size (Bazzaz \& Grinyer, 1981; Berger \& 
Ofek, 1995; Collis et al., 2007; Leontiades \& Tezel, 1981), shared identity and values (Ohmae, 1989), work environment (Thurm, 2005), performance (Stubbart, 1982), and embeddedness (Nell \& Ambos, 2013). Particularly the number of studies that consider the influence of a firm's size on the CHQ and on its relationship to performance is notable. Although Leontiades and Tezel (1981) find that the intensity of corporate planning at the CHQ depends on a firm's size, the other studies' cumulative findings suggest that firm size does affect the CHQ's structure (Bazzaz \& Grinyer, 1981; Collis et al., 2007). For example, Bazzaz and Grinyer (1981) find a positive correlation between the number of staff in the CHQ's planning subunit and firm size. Further, Collis and colleagues (2007) reveal that the size and structure of the CHQ depend on a firm's size.

\section{The CHQ and Environmental Factors (4-1)}

Previous CHQ research also considers the firm's external context and its impact on the CHQ. Scholars have explored various factors related to the firm's geography, industry and market, and other environmental factors, for example, stakeholder.

Geography. The literature that considers geographic aspects either examines the CHQ in a specific geographic context, reviewed earlier as the CHQ location, or explores international differences of the CHQ. There are only few studies in the latter strand. They explore international differences of the CHQ arguing that the institutional, legal, and cultural heritage of different countries will have significant effects on the CHQ (Collis et al., 2007, 2012; Schollhammer, 1971). Collis and colleagues (2012) find that "MNCs from different countries have substantially different corporate headquarters - US headquarters are large (255 median staff for a 20,000 FTE MNC) and European headquarters smaller (124)" (p. 260). Although they 
reveal an "administrative heritage" of the CHQ, there is little knowledge on the CHQ differences across geographic regions and countries.

Industry and market. Several scholars have addressed the role of a firm's industry and market in their study of the CHQ (e.g., Adner \& Helfat, 2003; Birkinshaw et al., 2006; Chandler, 1991; Greenwood, 1964; Greenwood et al., 1990; Porter, 1987; Raynor \& Bower, 2001; Yavitz \& Newman, 1982), focusing on diverse features such as industry attractiveness (Porter, 1987), transforming industries (Chandler, 1991), turbulent markets (Raynor \& Bower, 2001), and internationalization of markets and industries (Birkinshaw et al., 2006). For example, Chandler (1991) finds that firms in industries characterized by high capital intensity and high technological complexity require long-term investments in product-specific skills, which demands a strategic planning (or strategic control) CHQ style. On the other hand, for firms competing in industries with relatively low costs of capital and low complexity of specific skills, "synergies from R\&D, production and distribution are limited" (p. 49), and thus a financial control style is advantageous. Otherwise, Raynor and Bower (2001) suggest that the CHQ should provide more guidance in turbulent markets. In sum, the studies consistently find that the CHQ's role and integrating mechanisms generally depend on the firm's industry. Although initial efforts indicate industry's effect on specific CHQ aspects, such as industry differences in CHQ's corporate planning role (Greenwood, 1964), however, there is much less knowledge.

Other environmental factors. Relatively few CHQ studies consider environmental factors other than the geography, industry, and market. Other characteristics explored include government regulation (Russo, 1992), foreign currency-related shocks (Jacque \& Vaaler, 2001), and various stakeholders (Birkinshaw et al., 2006; Crilly, 2011). Particularly the recent studies' focus on different stakeholders expands our knowledge on environmental factors' influence on 
the CHQ. A study by Birkinshaw and colleagues (2006) provides evidence from a large-scale sample of Swedish MNCs that firms relocate CHQs primarily because of the demands of external stakeholders, especially international financial markets and shareholders. Extending the CHQ study to other stakeholders, Crilly (2011) analyzes 52 overseas subsidiaries and finds, among other things, that “although theory emphasizes external stakeholders' control over resources, internal control through the corporate parent can crowd out the voices of local stakeholders" (p. 694). While these studies suggest that diverse stakeholders, not just shareholders, matter for the CHQ and CHQ-operating unit relationships, insights are still sparse.

\section{The CHQ and Intermediate Outcomes (1-5)}

Several CHQ studies examine the CHQ's effect on intermediate outcomes, focusing either on process outcomes or on strategic outcomes.

Process outcomes. Scholars have analyzed the influence of the CHQ considering not only a large variety of process-related outcomes but also different levels of analysis, such as the CHQ, operating unit, and firm levels. The process outcomes in previous studies include CHQ's early recognition of investment opportunities (Tan \& Vertinsky, 1996), CHQ's involvement in the subsidiary innovation process (Ciabuschi et al., 2011b), the intensity of CHQ intervention in the business unit decision-making process (Hungenberg, 1993), the effectiveness of the CHQsubsidiary relationship (Roth \& Nigh, 1992), CHQ attention (Bouquet \& Birkinshaw, 2008), the success of the corporate initiative process (Darragh \& Campbell, 2001), CHQ influence (Martinez \& Ricks, 1989), harmful CHQ intervention (Foss et al., 2012), corporate innovation importance (Ciabuschi et al., 2011a), and localization success (the extent to which expatriate managers are replaced by local employees) (Law et al., 2009). Although research on processrelated outcomes of the CHQ has only recently spurred, especially studies in the international 
business context, there is already a substantial variety of different outcomes and measurement approaches. Because of their process focus, most of the studies rely upon survey data.

Strategic outcomes. A relatively small strand of the literature considers the CHQ's effect on strategic outcomes, including corporate entrepreneurship (Batten, 2002), innovation (Birkinshaw \& Hood, 2001), strategic focus (Kaplan \& Norton, 2005), valid corporate strategies (Goold, 1996a), sequential foreign direct investments (Song, 2002), and CHQ-level change (Ferlie \& Pettigrew, 1996). Birkinshaw and Hood (2001), for example, perform a qualitative analysis of more than $50 \mathrm{MNCs}$ and find that formal and informal communication channels between the CHQ and the firm's international subsidiaries are critical for innovation. The majority of these studies is practice-oriented and provides normative suggestions, and there are still only few academic attempts to contribute to our understanding of the CHQ's effect on strategic outcomes.

\section{The CHQ and Performance Outcomes (1-6)}

An important stream of the literature is concerned with the extent to which the CHQ adds value to the overall firm and with related issues, such as analyzing the CHQ's costs and benefits.

Financial performance. Several studies explore the CHQ's effect on a firm's financial performance. Indeed, most of the literature on the CHQ is motivated by questions pointing to the CHQ' value contribution (e.g., Adner \& Helfat, 2003; Collis \& Montgomery, 1998; Darragh \& Campbell, 2001; Goold \& Campbell, 1987; Hungenberg, 1993; Porter, 1987). Studies in this vein rely predominantly on accounting-based measures of firm performance, including return on assets (Adner \& Helfat, 2003; Berger \& Ofek, 1995; Hill et al., 1992; Hoskisson, 1987; Van Oijen \& Douma, 2000), return on equity (Russo, 1992; Van Oijen \& Douma, 2000), and return on sales (Markides \& Williamson, 1996; Van Oijen \& Douma, 2000), and to a lesser extent on 
market-based measures, such as market/shareholder returns (Collis et al., 2007; Hitt \& Ireland, 1986) and various multiples (Berger \& Ofek, 1995). Interestingly, the few studies that explore a CHQ's direct effect on firm performance reveal no significant association. Although Collis and colleagues (2007) identify a positive correlation between CHQ size and (self-reported) performance, they cannot determine the direction of causation.

Measuring the contribution of the CHQ to firm performance is difficult because the CHQ's benefits typically become visible via an enhanced operating unit performance (e.g., Collis \& Montgomery, 1997; Pettifer, 1998). Previous studies have therefore either analyzed CHQ's effect on operating unit performance or considered one or multiple contingencies of the CHQ-performance relationship. First, there is sparse evidence that CHQ characteristics (Russo, 1992) and the CHQ-operating unit relationship (Gupta, 1987) affect operating unit performance. Second, the results of the numerous studies that consider contingencies of the CHQ-performance relationship provide strong empirical that the fit between the CHQ and the operating units (e.g., Collis et al., 2007; Markides \& Williamson, 1994; Van Oijen \& Douma, 2000), the organization structure (e.g., Hill et al., 1992; Hitt \& Ireland, 1986; Hoskisson, 1987; Markides \& Williamson, 1996), and the environment (Adner \& Helfat, 2003), results in superior firm performance.

Other performance outcomes. In addition to examining CHQ's effect on a firm's financial performance, several studies have also considered other performance outcomes, such as the costs and benefits of the CHQ (Collis \& Montgomery, 1997; Pettifer, 1998; Rutenberg, 1969; Tomassen et al., 2012), perceived performance measures (Nell \& Ambos, 2013), and survival/failure rates (Lange, Boivie \& Henderson, 2009; Stubbart, 1982). For example, Collis and Montgomery (1997) summarize prior studies' findings and suggest that the costs of the CHQ range from 0.66 to 0.75 percent of the firm's assets, or about one percent of the revenues. As a 
minimum benchmark, they suggest a comparison of the CHQ costs with the fees charged by mutual funds. Particularly in recent years, scholars have performed surveys on the CHQ's role and design in multidivisional firms and considered self-reported performance measures of CHQ managers (Collis et al., 2007) or operating unit managers (Gupta, 1987; Nell \& Ambos, 2013). Nell and Ambos (2013), for example, focus on the CHQ's value added as perceived by 124 manufacturing subsidiaries' general managers and find that the MNC's external embeddedness is positively related to CHQ's value added. In sum, although previous studies suggest that the CHQ positively affects various performance outcomes, the overall evidence is still limited.

\section{SYNTHESIS AND RESEARCH AGENDA}

Research on the CHQ has the unique potential to contribute to our understanding of contemporary organizations. As presented above, there has accumulated an extensive literature on the CHQ in the multidivisional firm. Thanks to scholars' previous efforts, we already have a substantial knowledge on diverse CHQ aspects. Among other things, there is a thorough understanding of the CHQ's roles and prior studies have consistently provided support for a contingency perspective on the CHQ, for example, that the CHQ's design depends on internal and external factors. In other strands of the research, however, the insights are sparse and inconclusive, for instance, regarding the CHQ's performance consequences. Therefore, based on a synthesis of findings from the review, we identify major shortcomings and gaps and propose five high-priority research opportunities that demand particular attention: (1) The CHQ's nature and boundaries; (2) the CHQ's "functioning"; (3) the CHQ's staff(ing); (4) the CHQ's relationship with the operating units; and (5) the CHQ's impact. Overall, there is a need for a research agenda that builds upon the collective insights from the review but, at the same time, considers related literature's findings and novel ideas from practice. 
First, we encourage scholars to draw on the cumulative knowledge of the four individual research tracks and to benefit from cross-fertilization. This should include a consideration of the studies' findings on the CHQ in the multibusiness firm for future research on the MNC's CHQ, and vice versa. For example, Chandler (1991) notes, that "the decisions made by the senior executives at their headquarters have been absolutely critical to the performance of such multinational and multiproduct companies" (p. 31). Hence, many of the previous studies' results are possibly valid for multidivisional firms in general. Second, scholars should take stock of the previous practice-oriented work and use it as a stimulus to generate ideas for future academic efforts. In addition to the publications included in the formal review, we therefore also incorporate additional study reports in our research agenda (Kunisch, Müller-Stewens \& Collis, 2012; Young, 1993a; Young et al., 2000; Zimmermann \& Huhle, 2013). Third, we see a great potential that CHQ research may benefit from other research areas' findings, such as on crossfunctional collaboration and upper echelons. In combination with the gaps identified in the review, these findings pave the way for novel CHQ studies. In the following, we elaborate the high-priority research opportunities, and suggest promising theoretical perspectives and suitable methods for studying them (for exemplary corresponding research questions, see Table 2).

Insert Table 2 about here

\section{Opportunity 1: The CHQ's Nature and Boundaries}

The first opportunity for future CHQ research refers to the CHQ's nature and boundaries. Although many of the existing CHQ studies are concerned with the CHQ's characteristics, there is a need to advance and substantiate this knowledge in at least three areas. First, there are several, potentially value-adding, CHQ activities that did not receive sufficient if at all - scholarly attention, for example, the CHQ's role in managing corporate initiatives and 
programs. Second, studies of the CHQ's integrating mechanisms beyond mere control and planning, for example, socialization (Nohria \& Ghoshal, 1994) and procedural justice (Kim \& Mauborgne, 1993), are rare but needed, because these processes play an important role in the multidivisional firm. Third, there is some potential to extend our sparse knowledge on the CHQ's dynamic capabilities, which may contribute to our understanding on how the CHQ renews over time. In sum, scholars should draw upon related theories and examine these different CHQ characteristics' antecedents, their development paths, and consequences for the CHQ's (internal and external) boundaries and structure.

While we generally need to know more about the CHQ concept and its boundaries, research indicates that, over the past years, the CHQ has changed. The changes include the rise of new corporate-level functions and executives (Guadalupe, Li \& Wulf, 2012; Menz, 2012), the dispersion of certain CHQ activities and roles across multiple locations (and units) (Desai, 2008; DuBrule, Bouquet \& Birkinshaw, 2010), and the 'blurring' of boundaries between the corporate and operating unit levels (Goold \& Campbell, 2002b). For example, Desai (2008) observes that firms are "redefining their homes by unbundling their headquarters functions and reallocating them opportunistically across nations" (p. 1). Some scholars even imagine the demise of the CHQ as a discrete entity (Pasternack \& Viscio, 1998). Therefore, future studies should center on the nature, antecedents, and implications of recently emerging CHQ types and designs by, for instance, drawing on institutional theories and longitudinal data sets.

In a related vein, there is a great opportunity to explore the CHQ's dynamic nature that is why and how firms change their CHQ over time. As indicated in the formal literature review, only few studies have dealt with the CHQ's transformation and redesign (Bazzaz \& Grinyer, 1981; Ferlie \& Pettigrew, 1996; Goold et al., 2001). Interestingly, several practice-oriented 
reports indicate that CHQ change is indeed an important phenomenon (Kunisch et al., 2012; Zimmermann \& Huhle, 2013). For example, a recent study of 761 firms in North America and Europe reveals that in two thirds of the firms the CHQ engaged in a "major change during the financial crisis and recessionary period (2007-2010)" (Kunisch et al., 2012: 6). The lack of established knowledge, particularly on changes of the CHQ's role and integrating mechanisms over time, calls for future research that incorporates a dynamic perspective on the CHQ and focuses on aspects such as the continuous alignment between the CHQ and the firm and its environment.

\section{Opportunity 2: The CHQ's 'Functioning'}

Future research also offers the opportunity to improve our understanding of the $C H Q$ 's 'functioning'. Particularly in light of the increasing complexity at the firm's corporate level due to, new organization designs (Foss et al., 2012), the increasing number of corporate functions (Guadalupe et al., 2012; Menz, 2012), and more demanding cross-business collaborations (Martin \& Eisenhardt, 2010), this is critical. However, although in-depth knowledge of the decision and collaboration processes employed within the CHQ seems to be foundational for developing effective CHQs, research on this topic is almost non-existent. As a starting point, scholars should therefore examine how these processes unfold in the CHQ by performing longitudinal qualitative studies or comprehensive surveys of CHQ management, focusing on select aspects of a CHQ's activities and integrating mechanisms, such as strategic decisionmaking and strategic planning.

A particularly promising area for future research is rooted in the observation that the CHQ comprises various functional units, for example, HR, IT, marketing, and strategy units, socalled corporate functions. Interestingly, only few studies have dealt with these CHQ sub-units 
or functions (Bazzaz \& Grinyer, 1981; Campbell et al., 2012; Collis et al., 2007; Kaplan \& Norton, 2005), and focused on the strategic, structural, and other factors that may affect the decision to have a specific corporate function in the CHQ. Similar to a recent study on the corporate HR function (Gospel \& Sako, 2010), we also encourage scholars to explore the nature and emergence of other corporate functions. For example, although recent studies findings' suggest that the corporate strategy function has become more important, as indicated by an increasing number of firm's with a chief strategy officer in the TMT (Menz \& Scheef, 2013), we have little insights into the "functioning" of this corporate function.

Relatedly, there is little knowledge on if and how the collaboration between the various corporate functions in the CHQ happens. Since dealing with complex strategic issues and corporate strategic initiatives typically involves multiple corporate functions (Darragh \& Campbell, 2001), understanding cross-functional collaboration within the CHQ is critical. Informed by prior research on the cross-functional collaboration within teams (Denison, Hart \& Kahn, 1996; Lovelace, Shapiro \& Weingart, 2001), studies in this vein should address diverse topics such as the coordination and communication processes that span the corporate functions' boundaries. Specifically, the CHQ's context as well as diversity of strategic decisions and initiatives, point to questions of the relative influence of various corporate functions. Informed by previous studies in the marketing domain (Homburg, Workman \& Krohmer, 1999), scholars should examine the corporate functions' relative influence within the CHQ drawing on power and resource-dependence theories.

\section{Opportunity 3: The CHQ's Staff(ing)}

An additional opportunity for future research relates to the CHQ's staff(ing), which is critical given the considerable importance but small size of a typical CHQ. While there are some 
general insights on CHQ staffing in the literature on the CHQ's structure, for example, regarding the number of CHQ staff (Collis et al., 2007; Kunisch et al., 2012; Young, 1993a; Young et al., 2000; Zimmermann \& Huhle, 2013), we still have little knowledge on the characteristics of the people employed in the multidivisional firm's CHQ beyond the TMT. To enhance our understanding of the (unique) characteristics of CHQ staff, scholars should build on insights from the related TMT, executive selection, and HR literatures and focus on important aspects, such as the demographic characteristics and the composition of CHQ staff. Particularly, future research that draws upon Hambrick and Mason's (1984) upper echelons theory may inform the study of the CHQ in two areas.

First, prior CHQ studies indicate that the tasks of CHQ staff vary from those of line managers in the operating units, for example, regarding the coordination and integration requirements (Darragh \& Campbell, 2001; Kleinbaum \& Stuart, 2013). For example, according to Kleinbaum and Stuart's (2013) recent social network analysis of corporate staff, "members of the corporate center do have networks that appear to be better optimized for coordinating across disparate organizational and social structures than do employees in the line organization" (p. 2). Consequently, CHQ managers require different qualifications and are thus likely to have different previous career paths than managers in the firm's operating units. Similar to existing executive selection and strategic HR research (Datta, Deepak \& Guthrie, 1994; Guthrie \& Datta, 1998; Rajagopalan \& Datta, 1996), future studies should therefore develop knowledge on the specific selection criteria for the recruitment of CHQ staff, considering the CHQ in general as well as individual corporate functions as well as the organizational and environmental contexts.

Second, consistent with Hambrick and Mason's (1984) original notion, scholars could regard "the CHQ as a reflection of its top managers" and study how CHQ executives with 
different backgrounds affect the CHQ's roles and integrating mechanisms. Prior research has revealed that an individual executive's tenure, education, and functional experience affect outcomes (for an overview, see Finkelstein, Hambrick \& Cannella, 2009). For example, studies find that CEOs with a finance background are likely to be found in firms that are more diversified and/or more active acquirers (Jensen \& Zajac, 2004; Song, 1982). Similarly, executives at the CHQ with such a background may favor financial controls over other types of control. To enhance our knowledge on the CHQ "functioning" and staffing, future studies should analyze these executive characteristics' effects on the CHQ, also considering individual executives other than the CEO, such as the functional heads located at the CHQ (Menz, 2012).

\section{Opportunity 4: The CHQ's Relationship with the Operating Units}

There is also a need to substantiate and extend previous studies' findings on the CHQ's relationship with the operating units. Since the value contribution of the CHQ typically unfolds via the improved operating unit performance (Porter, 1987), the CHQ-operating unit relationship should still be among the most important areas of future CHQ research. Particularly in this area, prior studies' findings on multibusiness and multinational firms may inform each other. While research on the CHQ in the multibusiness firm predominantly focuses on the fit between the CHQ and the business units (Balderston, 1962; Campbell et al., 1995a), as well as on CHQ's role in cross-business collaboration (Martin \& Eisenhardt, 2010), the vertical relationships between the CHQ and individual business units have been largely neglected in academic and practiceoriented debates. Indeed, Goold and colleagues (1998) note that the CHQ should focus on its "ability to improve performance in each individual business as a stand-alone entity" (p. 310). Addressing this topic, we recommend studies that explore how the CHQ can "leverage" specific capabilities, such as alliance, innovation, and M\&A capabilities, to the firm's operating units. 
In addition, scholars should further examine the processes in the relationship between the CHQ and the firm's operating units. While this has been a dominant theme in CHQ research in the international business tradition, we know less about the processes in CHQ-business unit relationships. Specifically, we encourage scholars to follow one or more of the following three lines of enquiry. First, and related to the previous paragraph, future research should explore how the CHQ-operating unit relationships should be designed, considering different CHQ roles and types of integrating mechanisms. For example, studies could build on Joseph and Ocasio's (2012) recent inductive study of General Electric and analyze CHQ-operating unit interactions across a larger sample of firms. Second, future work in this area should account for additional operating unit characteristics, such as an international subsidiary's local strategy. For example, as Gupta (1987) finds, the CHQ-operating unit relationship may be contingent upon the operating unit's competitive strategy. Third, to understand the complex CHQ-operating unit relationships, we advocate process studies on the implementation of corporate strategies that incorporate multiple perspectives, including the operating units' perspectives.

\section{Opportunity 5: The CHQ's Impact}

One of the most promising opportunities for future research refers to the urgent need to enhance the inconclusive knowledge of the $C H Q$ 's impact on process, strategic, and performance outcomes. First, although scholars have recently begun to study the CHQ's effect on process

outcomes, for example, CHQ attention (Bouquet \& Birkinshaw, 2008), this research is still relatively sparse and predominantly in the context of the MNC. Otherwise, studies on the CHQ's role in the multibusiness firm have often "black-boxed" such process outcomes. Hence, there is a great potential for future studies of the CHQ's effect on process outcomes in the multidivisional firm. Our review indicates that efforts to understand how the CHQ's roles and integrating 
mechanisms affect a firm's strategy processes, for example, strategic decision-making and strategy implementation, will be worthwhile. To explore these topics, scholars should focus not only on process outcomes on the CHQ level but also on the business unit level, for example, by performing survey-based research.

Second, there is only a small strand of the literature that deals with the CHQ's impact on strategic outcomes. Since the CHQ typically performs multiple activities that are supposed to affect a firm's strategy, studying related outcomes may contribute to academic research on the CHQ. Interestingly, predominantly practice-oriented studies have considered strategic outcomes, such as corporate entrepreneurship (Batten, 2002), innovation (Birkinshaw \& Hood, 2001), and strategic focus (Kaplan \& Norton, 2005). We encourage scholars therefore to use these studies' initial insights and investigate CHQ's effect on strategic outcomes. Such outcomes can be either more general, such as corporate strategic change (Wiersema \& Bantel, 1992), or refer to specific strategic CHQ activities and capabilities, such as the success of mergers and acquisitions, alliances, or strategic initiatives and programs.

Third, we need to enhance our understanding of the CHQ's impact on performance outcomes. Previous studies considered the CHQ's general effect on firm's financial performance, and especially emphasized the importance of the fit between the CHQ's role, capabilities, and structure and organizational or environmental contingencies (Adner \& Helfat, 2003; Collis et al., 2007; Hoskisson, 1987; Markides \& Williamson, 1994). Despite these prior efforts, scholars should continue to examine CHQ's effect on a firm's financial performance, also considering the impact of individual CHQ activities, integrating mechanisms, and capabilities. While previous CHQ research predominantly relied upon objective measures of performance, studies that also consider perceived measures of a CHQ's value added (Nell \& Ambos, 2013) will contribute to 
CHQ research, as they allow for directly measuring the CHQ's benefit. Finally, we encourage scholars to explore the CHQ's general effect on a firm's long-term survival and prosperity, the CHQ's ultimate responsibility.

\section{CONCLUSION}

This article's objective was to offer a review and integration of the diverse and fragmented literature on the CHQ. Instead of limiting the review to a particular strand, we considered a comprehensive analysis of the literature in the economic, organization, practiceoriented, and international business traditions as more suitable to determining both its accomplishments and shortcomings, and to benefit from the cumulative studies' findings. In essence, we found that although CHQ research recently spurred, there are many exciting opportunities for future studies. We hope that this article encourages scholars to substantiate and extend the existing knowledge on the CHQ and thereby to contribute to our understanding of the multidivisional firm. 


\section{REFERENCES}

Aarland, K., Davis, J. C., Henderson, J. V., \& Ono, Y. 2007. Spatial Organization of Firms: The Decision to Split Production and Administration. RAND Journal of Economics, 38(2): 480494.

Adner, R., \& Helfat, C. E. 2003. Corporate Effects and Dynamic Managerial Capabilities. Strategic Management Journal, 24: 1011-1025.

Alexander, M. 1992. Disintermediation - Redefining the Role of Corporate Headquarters. Long Range Planning, 25(6): 110-112.

Alfoldi, E. A., Clegg, L. J., \& McGaughey, S. L. 2012. Coordination at the Edge of the Empire: The Delegation of Headquarters Functions through Regional Management Mandates. Journal of International Management, 18(3): 276-292.

Ambos, T. C., Andersson, U., \& Birkinshaw, J. 2010. What Are the Consequences of InitiativeTaking in Multinational Subsidiaries? Journal of International Business Studies, 41(7): 1099-1118.

Baaij, M. G., Mom, T. J. M., Van Den Bosch, F. A. J., \& Volberda, H. W. 2012. Should Top Management Relocate across National Borders? MIT Sloan Management Review, 53(2): 1718.

Baaij, M. G., Van Den Bosch, F. A. J., \& Volberda, H. W. 2004. The International Relocation of Corporate Centres: Are Corporate Centres Sticky? European Management Journal, 22(2): 141-149.

Balderston, F. E. 1962. Models of Multiple Branch Organization. California Management Review, 4(3): 40-57.

Baliga, B. R., \& Jaeger, A. M. 1984. Multinational Corporations: Control Systems and Delegation Issues. Journal of International Business Studies(Fall): 25-40.

Barney, J. B. 1991. Firm Resources and Sustained Competitive Advantage. Journal of Management, 17: 99-120.

Bartlett, C. A., \& Ghoshal, S. 1989. Managing across Borders: The Transnational Solution. Boston, MA: Harvard Business School Press.

Barton, H., Brown, D., Cound, J., Marsh, P., \& Willey, K. 1992. Does Top Management Add Value to Investment Decisions? Long Range Planning, 25(5): 43-58.

Batten, F. 2002. Out of the Blue and into the Black. Harvard Business Review, 80(4): 112-119.

Bazzaz, S. J., \& Grinyer, P. H. 1981. Corporate Planning in the U.K.: The State of the Art in the 70s. Strategic Management Journal, 2(2): 155-168. 
Berg, N. A. 1969. What's Different About Conglomerate Management? Harvard Business Review, 47(6): 112-120.

Berg, N. A. 1977. The Conglomerate - Its Strategy and Structure. Business History Conference.

Berger, P. G., \& Ofek, E. 1995. Diversification's Effect on Firm Value. Journal of Financial Economics, 37: 39-65.

Berle, A. A., \& Means, G. C. 1932. The Modern Corporation and Private Property. New York, NY: Macmillan.

Birkinshaw, J., Braunerhjelm, P., Holm, U., \& Terjesen, S. 2006. Why Do Some Multinational Corporations Relocate Their Headquarters Overseas? Strategic Management Journal, 27: 681-700.

Birkinshaw, J., \& Hood, N. 2001. Unleash Innovation in Foreign Subsidiaries. Harvard Business Review, 79(3): 131-137.

Bouquet, C., \& Birkinshaw, J. 2008. Weight Versus Voice: How Foreign Subsidiaries Gain Attention from Corporate Headquarters. Academy of Management Journal, 51(3): 577-601.

Bowman, C., \& Ambrosini, V. 2003. How the Resource-Based and the Dynamic Capability Views of the Firm Inform Corporate-Level Strategy. British Journal of Management, 14: 289-303.

Campbell, A. 1995. Vertical Integration Synergy or Seduction? Long Range Planning, 28(2): 126-128.

Campbell, A. 1999. Tailored, Not Benchmarked. A Fresh Look at Corporate Planning. Harvard Business Review, 77(2): 41.

Campbell, A., Goold, M., \& Alexander, M. 1995a. Corporate Strategy: The Quest for Parenting Advantage. Harvard Business Review, 37(March/April): 120-132.

Campbell, A., Goold, M., \& Alexander, M. 1995b. The Value of the Parent Company. California Management Review, 38(1): 79-97.

Campbell, A., Kunisch, S., \& Müller-Stewens, G. 2012. Are CEOs Getting the Best from Corporate Functions? MIT Sloan Management Review, 53(3): 12-14.

Chan, C. M., \& Makino, S. 2007. Legitimacy and Multi-Level Institutional Environments: Implications for Foreign Subsidiary Ownership Structure. Journal of International Business Studies, 38(4): 621-638.

Chandler, A. D. 1962. Strategy and Structure: Chapters in the History of the American Industrial Enterprise. Cambridge, MA: MIT Press. 
Chandler, A. D. 1991. The Functions of the HQ Unit in the Multibusiness Firm. Strategic Management Journal, 12(1): 31-50.

Chen, D., Park, S. H., \& Newburry, W. 2009. Parent Contribution and Organizational Control in International Joint Ventures. Strategic Management Journal, 30(11): 1133-1156.

Ciabuschi, F., Dellestrand, H., \& Martín, O. M. 2011a. Internal Embeddedness, Headquarters Involvement, and Innovation Importance in Multinational Enterprises. Journal of Management Studies, 48(7): 1612-1639.

Ciabuschi, F., Forsgren, M., \& Martín, O. M. 2011b. Rationality Vs. Ignorance: The Role of MNE Headquarters in Subsidiaries' Innovation Processes. Journal of International Business Studies, 42(7): 958-970.

Coase, R. H. 1937. The Nature of the Firm. Economica, 4(16): 386-405.

Collis, D. J., \& Montgomery, C. A. 1997. Corporate Strategy: Resources and the Scope of the Firm. Boston, MA: McGraw-Hill.

Collis, D. J., \& Montgomery, C. A. 1998. Creating Corporate Advantage. Harvard Business Review, 76(3): 70-84.

Collis, D. J., Young, D., \& Goold, M. 2007. The Size, Structure, and Performance of Corporate Headquarters. Strategic Management Journal, 28: 383-405.

Collis, D. J., Young, D., \& Goold, M. 2012. The Size and Composition of Corporate Headquarters in Multinational Companies: Empirical Evidence. Journal of International Management, 18(3): 260-275.

Crilly, D. 2011. Predicting Stakeholder Orientation in the Multinational Enterprise: A MidRange Theory. Journal of International Business Studies, 42(5): 694-717.

Darragh, J., \& Campbell, A. 2001. Why Corporate Initiatives Get Stuck? Long Range Planning, 34(1): 33-52.

Datta, D. K., Deepak, K., \& Guthrie, J. P. 1994. Executive Succession: Organizational Antecedents of CEO Characteristics. Strategic Management Journal, 15(569-579).

Davis, J. C., \& Henderson, J. V. 2008. The Agglomeration of Headquarters. Regional Science \& Urban Economics, 38(5): 445-460.

Denison, D. R., Hart, S. L., \& Kahn, J. A. 1996. From Chimneys to Cross-Functional Teams: Developing and Validating a Diagnostic Model. Academy of Management Journal, 39(4): 1005-1023.

Desai, M. A. 2008. The Decentering of the Global Firm. Harvard Business School Working Paper. Boston, MA: Harvard Business School. 
DuBrule, A., Bouquet, C., \& Birkinshaw, J. 2010. Global Growth at Irdeto (B): A Dual HQ Strategy). IMD Case Study(IMD-3-2090): 1-7.

Eisenhardt, K. M. 1985. Control: Organizational and Economical Approaches. Management Science, 31: 134-149.

Eisenhardt, K. M., \& Martin, J. A. 2000. Dynamic Capabilities: What Are They? Strategic Management Journal, 21: 1105-1121.

Fama, E. F. 1970. Efficient Capital Markets: A Review of Theory and Empirical Work. The Journal of Finance, 25(2): 383-417.

Ferlie, E., \& Pettigrew, A. 1996. The Nature and Transformation of Corporate Headquarters: A Review of Recent Literature and a Research Agenda. Journal of Management Studies, 33(4): 495-523.

Finkelstein, S., Hambrick, D. C., \& Cannella, A. A. 2009. Strategic Leadership: Theory and Research on Executives, Top Management Teams, and Boards. Oxford: Oxford University Press.

Foss, K., Foss, N. J., \& Nell, P. C. 2012. MNC Organizational Form and Subsidiary Motivation Problems: Controlling Intervention Hazards in the Network MNC. Journal of International Management, 18(3): 247-259.

Foss, N. J. 1997. On the Rationales of Corporate Headquarters. Industrial and Corporate Change, 6(2): 313-338.

Galbraith, J. R. 1973. Designing Complex Organizations. Reading, MA: Addison-Wesley.

Garvin, D. A., \& Levesque, L. C. 2008. The Multiunit Enterprise. Harvard Business Review, 86(6): 106-117.

Goold, M. 1996a. Parenting Strategies for Multibusiness Companies. Long Range Planning, 29(3): 419-421.

Goold, M. 1996b. Parenting Strategies for the Mature Business. Long Range Planning, 29(3): 358-369.

Goold, M., \& Campbell, A. 1987. Strategies and Styles: The Role of the Centre in Managing Diversified Companies. Oxford: Blackwell.

Goold, M., \& Campbell, A. 2002a. Do You Have a Well-Designed Organization? Harvard Business Review, 80(3): 117-124.

Goold, M., \& Campbell, A. 2002b. Parenting in Complex Structures. Long Range Planning, 35(3): 219-243. 
Goold, M., Campbell, A., \& Alexander, M. 1994. Corporate-Level Strategy: Creating Value in the Multibusiness Company. New York, NY: John Wiley \& Sons.

Goold, M., Campbell, A., \& Alexander, M. 1998. Corporate Strategy and Parenting Theory. Long Range Planning, 31(2): 308-314.

Goold, M., Pettifer, D., \& Young, D. 2001. Redesigning the Corporate Centre. European Management Journal, 19(1): 83.

Gospel, H., \& Sako, M. 2010. The Unbundling of Corporate Functions: The Evolution of Shared Services and Outsourcing in Human Resource Management. Industrial and Corporate Change, 19(5): 1367-1396.

Govindarajan, V. 1988. A Contingency Approach to Strategy Implemnetation at the BusinessUnit Level: Integrating Administrative Mechanisms with Strategy. Academy of Management Journal, 31(4): 828-853.

Grant, R. M. 1996. Toward a Knowledge-Based Theory of the Firm. Strategic Management Journal, 17(Winter Special Issue): 109-122.

Greenwood, F. 1964. Management in Perspective Effective LRP Requires Action. Academy of Management Journal, 7(3): 224-228.

Greenwood, R., Hinings, C. R., \& Brown, J. 1990. "P2-Form" Strategic Management: Corporate Practices in Professional Partnerships. Academy of Management Journal, 33(4): 725-755.

Guadalupe, M., Li, H., \& Wulf, J. 2012. Who Lives in the C-suite? Organizational Structure and the Division of Labor in Top Management. Harvard Business School Working Paper 12059.

Gupta, A. K. 1987. SBU Strategies, Corporate-SBU Relations, and SBU Effectiveness in Strategy Implementation. Academy of Management Journal, 30(3): 477-500.

Guthrie, J. P., \& Datta, D. K. 1998. Corporate Strategy, Executive Selection, and Firm Performance. Human Resource Management, 37(2): 101-115.

Hambrick, D. C., \& Mason, P. A. 1984. Upper Echelons: The Organization as a Reflection of Its Top Managers Academy of Management Review, 9(2): 193-206.

Hanan, M. 1969. Corporate Growth through Internal Spin-Outs. Harvard Business Review, 47(6): 55-67.

Hansen, O. C., \& Peytz, M. 1991. Designing the Corporate Center. McKinsey Quarterly, 1991(3): 128-139.

Henderson, J. V., \& Ono, Y. 2008. Where Do Manufacturing Firms Locate Their Headquarters? Journal of Urban Economics, 63(2): 431-450. 
Hill, C. W. L., Hitt, M. A., \& Hoskisson, R. E. 1992. Cooperative Versus Competitive Structures in Related and Unrelated Diversified Firms. Organization Science, 3(4): 501-521.

Hill, C. W. L., \& Hoskisson, R. E. 1987. Strategy and Structure of the Multiproduct Firm. Academy of Management Review, 12(2): 331-341.

Hitt, M. A., \& Ireland, R. D. 1986. Relationships among Corporate Level Distinctive Competences, Diversification Strategy, Corporate Structure and Performance. Journal of Management Studies, 23(4): 401-416.

Hitt, M. A., \& Ireland, R. D. 1987. Building Competitive Strength in International Markets. Long Range Planning, 20(1): 115-122.

Homburg, C., Workman, J. P., \& Krohmer, H. 1999. Marketing's Influence within the Firm. Journal of Marketing, 63(2): 1-17.

Hoskisson, R. E. 1987. Multidivisional Structure and Performance: The Contingency of Diversification Strategy. Academy of Management Journal, 30: 625-644.

Howard, R. 1991. The Designer Organization: Italy's Gft Goes Global. Harvard Business Review, 69(5): 28-44.

Hungenberg, H. 1993. How to Ensure That Headquarters Add Value. Long Range Planning, 26(6): $62-73$.

Jacque, L. L., \& Vaaler, P. M. 2001. The International Control Conundrum with Exchange Risk: An Eva Framework. Journal of International Business Studies, 32(4): 813.

Jensen, M., \& Zajac, E. J. 2004. Corporate Elites and Corporate Strategy: How Demographic Preferences and Structural Position Shape the Scope of the Firm. Strategic Management Journal, 25: 507-524.

Jensen, M. C., \& Meckling, W. 1976. Theory of the Firm: Managerial Behavior, Agency Costs, and Ownership Structure. Journal of Financial Economics, 3: 305-360.

Joseph, J., \& Ocasio, W. 2012. Architecture, Attention, and Adaptation in the Multibusiness Firm: General Electric from 1951 to 2001. Strategic Management Journal, 33(6): 633-660.

Kaplan, R. S., \& Norton, D. P. 2005. The Office of Strategy Management. Harvard Business Review, 83(10): 72-80.

Kim, W. C., \& Mauborgne, R. A. 1993. Procedural Justice, Attitudes, and Subsidiary Top Management Compliance with Multinationals' Corporate Strategic Decisions. Academy of Management Journal, 36(3): 502-526.

Kleinbaum, A. M., \& Stuart, T. E. 2013. Inside the Black Box of the Corporate Staff: Social Networks and the Implementation of Corporate Strategy. Strategic Management Journal, forthcoming: 1-24. 
Knight, F. H. 1921. Risk, Uncertainty and Profit. New York: Augustus M. Kelley.

Kono, T. 1999. A Strong Head Office Makes a Strong Company. Long Range Planning, 32(2): 225-236.

Kunisch, S., Müller-Stewens, G., \& Collis, D. J. 2012. Housekeeping at Corporate Headquarters: International Trends in Optimizing the Size and Scope of Corporate Headquarters, Survey Report. St. Gallen/Boston: University of St. Gallen/Harvard Business School.

Laamanen, T., Simula, T., \& Torstila, S. 2012. Cross-Border Relocations of Headquarters in Europe. Journal of International Business Studies, 43: 187-210.

Lange, D., Boivie, S., \& Henderson, A. D. 2009. The Parenting Paradox: How Multibusiness Diversifiers Endorse Disruptive Technologies While Their Corporate Children Struggle. Academy of Management Journal, 52(1): 179-198.

Law, K. S., Song, L. J., Wong, C.-S., \& Chen, D. 2009. The Antecedents and Consequences of Successful Localization. Journal of International Business Studies, 40(8): 1359-1373.

Leontiades, M., \& Tezel, A. 1981. Some Connections between Corporate-Level Planning and Diversity. Strategic Management Journal, 2(4): 413-418.

Lorsch, J. W., \& Allen, S. A. 1973. Managing Diversity and Interdependence: An Organizational Study of Multidivisional Firms. Boston, MA: Graduate School of Business Administration, Harvard University.

Lovelace, K., Shapiro, D. L., \& Weingart, L. R. 2001. Maximiztng Cross-Functional New Product Teams' Innovativeness and Constraint Adherence: A Conflict Communications Perspectiive. Academy of Management Journal, 44(4): 779-793.

MacMillan, I. C., \& Meshulach, A. 1983. Replacement Versus Expansion - Dilemma for Mature United-States Businesses. Academy of Management Journal, 26(4): 708-726.

Mahnke, V., Ambos, B., Nell, P. C., \& Hobdari, B. 2012. How Do Regional Headquarters Influence Corporate Decisions in Networked MNCs? Journal of International Management, 18(3): 293-301.

Markides, C. C. 2002. Corporate Strategy: The Role of the Centre. In A. Pettigrew, H. Thomas and R. Whittington (Eds.), Handbook of Strategy and Management: 98-111. London: Sage.

Markides, C. C. 2006. Corporate Strategy: The Role of the Centre. In A. Pettigrew, H. Thomas and R. Whittington (Eds.), Handbook of Strategy and Management: 98-112. London: Sage Publications.

Markides, C. C., \& Williamson, P. J. 1994. Related Diversification, Core Competences and Corporate Performance. Strategic Management Journal, 15(Summer Special Issue): 149165. 
Markides, C. C., \& Williamson, P. J. 1996. Corporate Diversification and Organizational Structure: A Resource-Based View. Academy of Management Journal, 39(2): 340-367.

Markovitz, H. 1952. Portfolio Selection. Journal of Finance, 7: 77-91.

Martin, J. A., \& Eisenhardt, K. M. 2010. Rewiring: Cross-Business-Unit Collaborations in Multibusiness Organizations. Academy of Management Journal, 53(2): 265-301.

Martinez, Z. L., \& Ricks, D. A. 1989. Multinational Parent Companies' Influence over Human Resource Decisions of Affiliates: U.S. Firms in Mexico. Journal of International Business Studies, 20(3): 465-487.

McInnes, J. M. 1971. Financial Control Systems for Multinational Operations: An Empirical Investigation. Journal of International Business Studies, 2(1): 11-28.

Menz, M. 2012. Functional Top Management Team Members: A Review, Synthesis, and Research Agenda. Journal of Management, 38(1): 45-80.

Menz, M., \& Scheef, C. 2013. Chief Strategy Officers: Contingency Analysis of Their Presence in Top Management Teams. Strategic Management Journal(Forthcoming): 1-22.

Miller, K. D., \& Waller, H. G. 2003. Scenarios, Real Options and Integrated Risk Management. Long Range Planning, 36(1): 93.

Mintzberg, H. 1979. The Structuring of Organizations: A Synthesis of the Research. Englewood Cliffs, NJ: Prentice-Hall.

Modigliani, F., \& Miller, M. H. 1958. The Cost of Capital, Corporation Finance and the Theory of Investment. American Economic Review, 48(3): 261-297.

Montague, R. 1986. Separate Corporate Headquarters Have an Economic Impact on Plant Operations. American Business Review, 4(1): 20.

Murdick, R. G. 1964. The Long-Range Planning Matrix. California Management Review, 7(2): 35-42.

Nell, P., \& Ambos, B. 2013. Parenting Advantage in the MNC: An Embeddedness Perspective on the Value Added by Headquarters. Strategic Management Journal, Forthcoming: 1-18.

Nohria, N., \& Ghoshal, S. 1994. Differentiated Fit and Shared Values - Alternatives for Managing Headquarters Subsidiary Relations. Strategic Management Journal, 15(6): 491502.

Nonaka, I. 1994. A Dynamic Theory of Organizational Knowledge Creation. Organization Science, 5(1): 14-37.

Ohmae, K. 1989. Planting for a Global Harvest. Harvard Business Review, 67(4): 136-145. 
Parks, F. N. 1974. What Role for the European HQ--and Where? Harvard Business Review, 52(4): 6 .

Pasternack, B. A., \& Viscio, A. J. 1998. The Centerless Corporation: A New Model for Transforming Your Organization for Growth and Prosperity. New York, NY: Simon \& Schuster.

Penrose, E. T. 1959. The Theory of the Growth of the Firm. Oxford: Blackwell.

Peteraf, M. A. 1993. The Cornerstones of Competitive Advantage: A Resource-Based View. Strategic Management Journal, 14(3): 179-191.

Pettifer, D. 1998. Measuring the Performance of the Corporate Centre. Long Range Planning, 31(5): 783-785.

Pitts, R. A. 1976. Diversification Strategies and Organizational Policies of Large Diversified Firms. Journal of Economics and Business, 28: 181-188.

Pitts, R. A. 1977. Strategies and Structures for Diversification. Academy of Management Journal, 20: 197-208.

Porter, M. E. 1987. From Competitive Advantage to Corporate Strategy. Harvard Business Review, 65(3): 43-59.

Prahalad, C. K., \& Doz, Y. 1987. The Multinational Mission. New York, NY: Free Press.

Rajagopalan, N., \& Datta, D. K. 1996. CEO Characteristics: Does Industry Matter? Academy of Management Journal, 39(1): 197-215.

Raynor, M. E., \& Bower, J. L. 2001. Lead from the Center: How to Manage Divisions Dynamically. Harvard Business Review, 79(5): 92-100.

Roth, K., \& Nigh, D. 1992. The Effectiveness of Headquarters-Subsidiary Relationships: The Role of Coordination, Control, and Conflict. Journal of Business Research, 25(4): 277-301.

Russo, M. V. 1992. Bureaucracy, Economic Regulation, and the Incentive Limits of the Firm. Strategic Management Journal, 13(2): 103-118.

Rutenberg, D. P. 1969. Planning for a Multi -- National Synergy. Long Range Planning, 2(2): 24-26.

Scharfstein, D. S. 1998. The Dark Side of Internal Capital Markets Ii: Evidence from Diversified Conglomerates. NBER Working Paper. Cambridge.

Scharfstein, D. S., \& Stein, J. C. 2000. The Dark Side of Internal Capital Markets: Divisional Rent-Seeking and Inefficient Investment. Journal of Finance, 55(6): 2537-2564.

Schollhammer, H. 1971. Organization Structures of Multinational Corporations. Academy of Management Journal, 14(3): 345-365. 
Semadeni, M., \& Cannella Jr., A. A. 2011. Examining the Performance Effects of Post Spin-Off Links to Parent Firms: Should the Apron Strings Be Cut? Strategic Management Journal, 32(10): 1083-1098.

Short, J. 2009. The Art of Writing a Review Article. Journal of Management, 35(6): 1312-1317.

Song, J. 2002. Firm Capabilities and Technology Ladders: Sequential Foreign Direct Investments of Japanese Electronic Firms in East Asia. Strategic Management Journal, 23(3): 191-210.

Song, J. H. 1982. Diversification Strategies and the Experience of Top Executives of Large Firms. Strategic Management Journal, 3(4): 377-380.

Spender, J.-C. 1996. Making Knowledge the Basis of a Dynamic Theory of the Firm. Strategic Management Journal, 17(Winter Special Issue): 45-62.

Stalk Jr., G. 2005. Rotate the Core. Harvard Business Review, 83(3): 18-19.

Strauss-Kahn, V., \& Vives, X. 2009. Why and Where Do Headquarters Move? Regional Science \& Urban Economics, 39(2): 168-186.

Stubbart, C. 1982. Are Environmental Scanning Units Effective? Long Range Planning, 15(3): 139-145.

Summers, C. W. 1965. Labor Relations in the Common Market. Harvard Business Review, 43(2): 148-160.

Takeuchi, R., Shay, J. P., \& Li, J. 2008. When Does Decision Autonomy Increase Expatriate Managers' Adjustment? An Empirical Test. Academy of Management Journal, 51(1): 45-60.

Tan, B., \& Vertinsky, I. 1996. Foreign Direct Investment by Japanese Electronics Firms in the United States and Canada: Modelling the Timing of Entry. Journal of International Business Studies, 27(4): 655-681.

Teece, D. J. 1980. Economies of Scope, and the Scope of the Enterprise. Journal of Economic Behavior and Organization 1: 223-247.

Teece, D. J. 1982. Towards an Economic Theory of the Multiproduct Firm. Journal of Economic Behavior and Organization, 3: 39-63.

Teece, D. J., Pisano, G., \& Shuen, S. 1997. Dynamic Capabilities and Strategic Management. Strategic Management Journal, 18(7): 509-533.

Thurm, D. 2005. Master of the House. Harvard Business Review, 83(10): 120-129.

Tomassen, S., Benito, G. R. G., \& Lunnan, R. 2012. Governance Costs in Foreign Direct Investments: A MNC Headquarters Challenge. Journal of International Management, 18(3): 233-246. 
Unknown. 1929. The Effect of the Subsidiary Corporation on the Parent Company. Harvard Business Review, 7(4): 496-504.

Vahlne, J.-E., Schweizer, R., \& Johanson, J. 2012. Overcoming the Liability of Outsidershipthe Challenge of HQ of the Global Firm. Journal of International Management, 18(3): 224232.

Van Oijen, A., \& Douma, S. 2000. Diversification Strategy and the Roles of the Centre. Long Range Planning, 33(4): 560-578.

Villalonga, B. 2004. Does Diversification Cause the "Diversification Discount"? Financial Management, 33(2): 5-27.

Webster, J., \& Watson, R. T. 2002. Analyzing the Past to Prepare for the Future: Writing a Literature Review. MIS Quarterly, 26(2): XIII-XXIII.

Wernerfelt, B. 1984. A Resource-Based View of the Firm. Strategic Management Journal, 5: 171-180.

Wiersema, M. F., \& Bantel, K. A. 1992. Top Management Team Demography and Corporate Strategic Change. Academy of Management Journal, 35(1): 91-121.

Williamson, O. E. 1975. Markets and Hierarchies: Analysis and Antitrust Implications: A Study in the Economics of Internal Organization. New York, NY: Free Press.

Williamson, O. E. 1981. The Economics of Organization: The Transaction Cost Approach. American Journal of Sociology, 87: 548-577.

Yavitz, B., \& Newman, W. H. 1982. What the Corporation Should Provide Its Business Units. Journal of Business Strategy, 3(1): 14-19.

Young, D. 1993a. The Headquarters Fact Book. London: Ashridge Strategic Management Centre.

Young, D. 1993b. Headquarters Staff - Products of History or Sources of Distinctive Skills. Long Range Planning, 26(5): 139-141.

Young, D. 1998a. Benchmarking Corporate Headquarters. Long Range Planning, 31(6): 933936.

Young, D., \& Goold, M. 1993. Effective Headquarters Staff - a Guide to the Size, Structure and Role of Corporate Headquarters Staff. London: Ashridge Strategic Management Centre.

Young, D., Goold, M., Blanc, G., Bühner, R., Collis, D., Eppink, J., Kagono, T., \& Jiménez Seminario, G. 2000. Corporate Headquarters: An International Analysis of Their Roles and Staffing. London: Pearson Education. 
Young, D. J. 1998b. Benchmarking Corporate Headquarters. Long Range Planning, 31(6): 933936.

Zimmermann, T., \& Huhle, F. 2013. Corporate Headquarters Study 2012 - Developing Value Adding Capabilities to Overcome the Parenting Advantage Paradox. Munich: Roland Berger Strategy Consultants. 
TABLE 1

Traditions/Streams in CHQ Research

\begin{tabular}{|c|c|c|c|c|}
\hline & $\begin{array}{c}\text { Economic } \\
\text { Perspective }\end{array}$ & $\begin{array}{l}\text { Organization } \\
\text { Perspective }\end{array}$ & $\begin{array}{c}\text { Practice-oriented/Normative } \\
\text { Perspective }\end{array}$ & $\begin{array}{c}\text { International Business } \\
\text { Perspective }\end{array}$ \\
\hline Typical CHQ terms & Parent company, parent firm & $\begin{array}{l}\text { General office, corporate } \\
\text { headquarters }\end{array}$ & $\begin{array}{l}\text { Corporate parent, corporate } \\
\text { center, corporate office, head } \\
\text { office }\end{array}$ & Corporate headquarters \\
\hline Research foci & $\begin{array}{l}\text { CHQ roles/governance styles; } \\
\text { CHQ/firm boundaries }\end{array}$ & $\begin{array}{l}\text { CHQ roles; CHQ } \\
\text { resources/capabilities; CHQ- } \\
\text { business units }\end{array}$ & $\begin{array}{l}\text { CHQ value added/destroyed; } \\
\text { normative guidelines for } \\
\text { corporate managers }\end{array}$ & $\begin{array}{l}\text { CHQ-international subsidiary } \\
\text { relationships; CHQ (re)location }\end{array}$ \\
\hline Theories/perspectives & $\begin{array}{l}\text { Transaction cost economics; } \\
\text { agency theory; financial } \\
\text { economics; real option theory }\end{array}$ & $\begin{array}{l}\text { Contingency theory; resource- } \\
\text { based view; dynamic } \\
\text { capabilities }\end{array}$ & $\begin{array}{l}\text { "Parenting theory", typically no } \\
\text { explicit theoretical lens }\end{array}$ & $\begin{array}{l}\text { Resource-dependence theory; } \\
\text { control theory; agency theory; } \\
\text { institutional theory; attention- } \\
\text { based view; stakeholder theory; } \\
\text { "international business theory" }\end{array}$ \\
\hline Intellectual roots/origins & $\begin{array}{l}\text { Coase (1937); Williamson } \\
(1975,1981) \text {; Teece (1980, } \\
\text { 1982); Markovitz (1952); } \\
\text { Modigliani \& Miller (1958); } \\
\text { Fama (1970) }\end{array}$ & $\begin{array}{l}\text { Chandler (1962); Galbraith } \\
\text { (1973); Lorsch \& Allen (1973); } \\
\text { Penrose (1959) }\end{array}$ & $\begin{array}{l}\text { Campbell, Goold, \& Alexander } \\
\text { (1995a); Goold \& Campbell } \\
\text { (1987); Goold, Campbell, \& } \\
\text { Alexander (1994) }\end{array}$ & $\begin{array}{l}\text { Baliga \& Jaeger (1984); Bartlett } \\
\text { \& Ghoshal (1989); Prahalad \& } \\
\text { Doz (1987) }\end{array}$ \\
\hline Methods & $\begin{array}{l}\text { Conceptual (including formal } \\
\text { modeling); empirical with } \\
\text { quantitative analyses of large- } \\
\text { scale data }\end{array}$ & $\begin{array}{l}\text { Qualitative analysis; } \\
\text { Quantitative analysis (e.g., } \\
\text { surveys and archival data) }\end{array}$ & $\begin{array}{l}\text { Conceptual (generic normative } \\
\text { frameworks); qualitative } \\
\text { analysis; illustrative case } \\
\text { studies }\end{array}$ & $\begin{array}{l}\text { Quantitative analysis (e.g., } \\
\text { surveys of subsidiaries in } \\
\text { multinational corporations) }\end{array}$ \\
\hline Exemplary studies & $\begin{array}{l}\text { Russo (1992); Semadeni \& } \\
\text { Cannella (2011) }\end{array}$ & $\begin{array}{l}\text { Adner \& Helfat (2003); } \\
\text { Chandler (1991); Collis \& } \\
\text { Montgomery (1997); Collis, } \\
\text { Young, \& Goold (2007) }\end{array}$ & $\begin{array}{l}\text { Darragh \& Campbell (2001); } \\
\text { Goold \& Campbell (2002b); } \\
\text { Hungenberg (1993) }\end{array}$ & $\begin{array}{l}\text { Birkinshaw, Braunerhjelm, } \\
\text { Holm, \& Terjesen (2006); } \\
\text { Bouquet \& Birkinshaw (2008); } \\
\text { Chen, Park, \& Newburry } \\
\text { (2009); Nell \& Ambos (2013) }\end{array}$ \\
\hline
\end{tabular}


TABLE 2

\section{Opportunities for Future CHQ Research}

\begin{tabular}{|c|c|}
\hline Research Opportunity & Exemplary Research Questions \\
\hline $\begin{array}{l}\text { Opportunity 1: } \\
\text { The CHQ's nature and } \\
\text { boundaries }\end{array}$ & $\begin{array}{l}\text { - What are characteristics of the CHQ in the contemporary corporation? Why and how do firms decide to adopt specific CHQ } \\
\text { types? What are the (internal and external) boundaries of the CHQ? } \\
\text { - What are the defining features of new and emerging CHQ types (e.g., virtual CHQ vs. large and representative CHQ)? } \\
\text { - How do institutional factors and firm's mimetic behavior affect the emergence of new CHQ types? } \\
\text { - Do firms change their CHQ types over time? If yes, when, how and why? }\end{array}$ \\
\hline $\begin{array}{l}\text { Opportunity 2: } \\
\text { The CHQ's 'functioning' }\end{array}$ & $\begin{array}{l}\text { - How do decision and collaboration processes within the CHQ function? Who is involved in/leads these processes? Are certain } \\
\text { process designs in the CHQ more effective than others? If so, why? } \\
\text { - Which strategic, structural, and other factors affect the decision to have a specific corporate function (e.g., HR, IT, marketing, } \\
\text { strategy) in the CHQ? Why and how do some firms decide to centralize more functions at the CHQ than others? } \\
\text { - How does the collaboration between the various corporate functions in the CHQ happen (specifically, when dealing with } \\
\text { different strategic issues/driving corporate initiatives)? } \\
\text { - To what extent and why are some corporate functions more influential than others? }\end{array}$ \\
\hline $\begin{array}{l}\text { Opportunity 3: } \\
\text { The CHQ's staff(ing) }\end{array}$ & $\begin{array}{l}\text { - What are the (e.g., demographic) characteristics of managers (and staff in general) at the CHQ? Do they differ from those of } \\
\text { the operating units? If so, how? } \\
\text { - How and why are some career paths/experiences more suitable to prepare an executive for a CHQ position than others? } \\
\text { - What are the requirements for a CHQ position (as opposed to a line management position) and how do they affect the selection } \\
\text { and development of candidates? Specifically, is a CHQ position a career springboard or dead-end? } \\
\text { - How do differences in the background of CHQ executives affect decisions regarding the role and design of the CHQ? }\end{array}$ \\
\hline $\begin{array}{l}\text { Opportunity 4: } \\
\text { The CHQ's relationship with } \\
\text { the operating units }\end{array}$ & $\begin{array}{l}\text { - To what extent and how do characteristics of the CHQ (e.g., roles, design) and of the firm's operating units (e.g., business } \\
\text { relatedness, geographic distance) affect the CHQ's relationship with the operating units? } \\
\text { - How do coordination and collaboration processes between the CHQ and the firm's operating units work? What is the role of } \\
\text { the CHQ in the implementation of corporate strategies in the firm's portfolio of operating units? } \\
\text { - To what extent and how can firms 'leverage' CHQ capabilities (e.g., alliance, HR, innovation, M\&A, and marketing } \\
\text { capabilities) to the operating units? How should these vertical relationships be designed? } \\
\text { - What is the operating units' perspective on the CHQ-operating unit relationships? When, why, and how do they affect the } \\
\text { design and effectiveness of these relationships? }\end{array}$ \\
\hline $\begin{array}{l}\text { Opportunity 5: } \\
\text { The CHQ's impact }\end{array}$ & $\begin{array}{l}\text { - How does the CHQ generally affect the performance of the firm's individual operating units and of the overall firm, including } \\
\text { alternative measure of performance (e.g., symbolic value, perceived value of internal and external stakeholders)? } \\
\text { - What is the impact of individual CHQ aspects, such as that of certain capabilities or roles, on performance outcomes? } \\
\text { - To what extent and how does the CHQ affect intermediate outcomes on multiple levels, such as strategic change and renewal } \\
\text { on the operating unit and firm levels, as well as individual strategic activities (e.g., corporate initiatives and programs, M\&A)? } \\
\text { - How do multiple contingencies and their interactions affect CHQ's effect on intermediate and performance outcomes? }\end{array}$ \\
\hline
\end{tabular}




\section{FIGURE 1}

\section{Organizing Framework of CHQ Research}

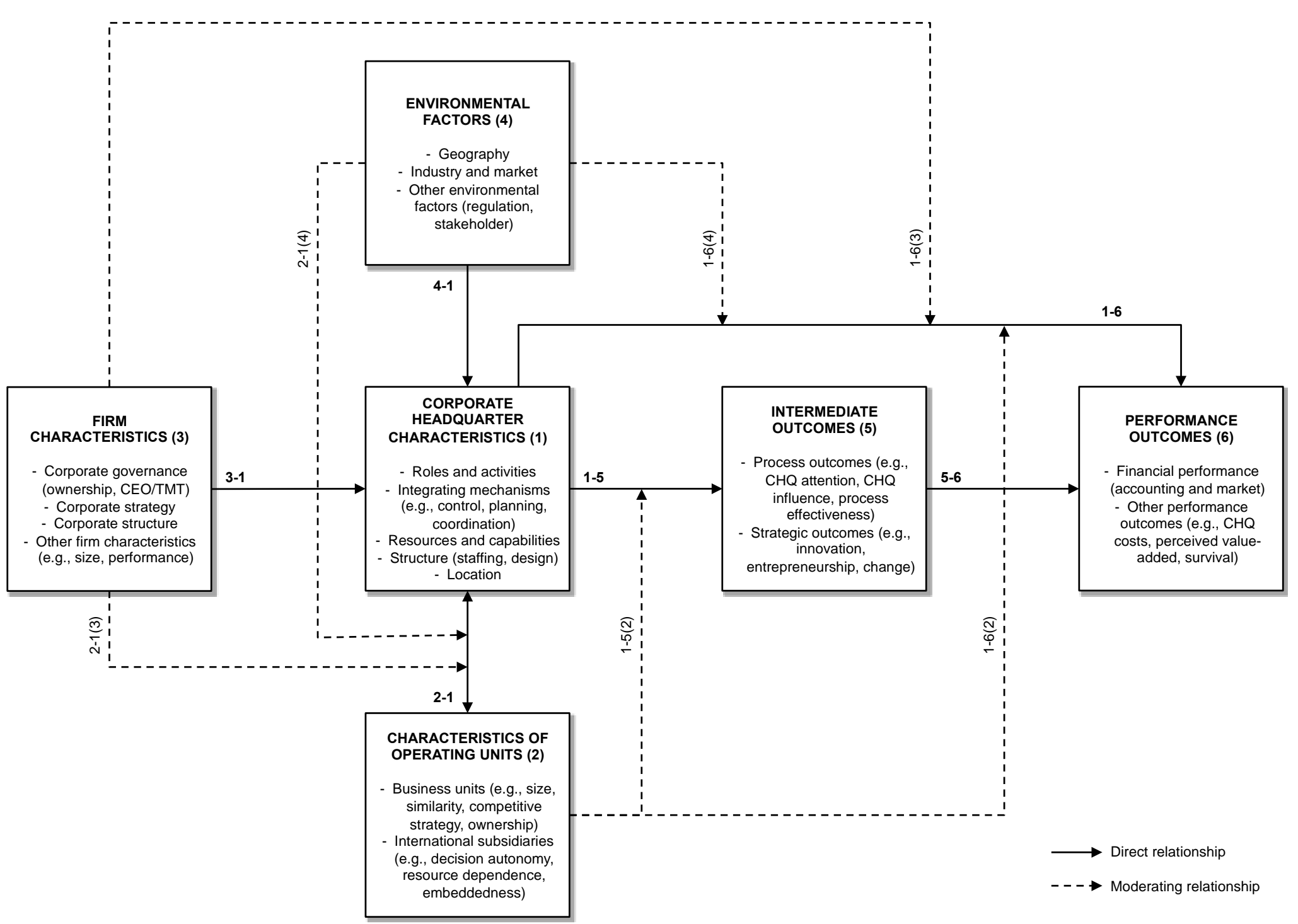




\section{APPENDIX 1}

\section{Selected CHQ Terms and Definitions (in Chronological Order)}

\begin{tabular}{|c|c|c|}
\hline Term & Definition & Source \\
\hline General office & $\begin{array}{l}\text { "At the top is a general office. There, general executives and staff specialists coordinate, appraise, and plan } \\
\text { goals and policies and allocate resources for a number of quasi-autonomous, fairly self-contained } \\
\text { divisions" (p. 9) }\end{array}$ & (Chandler, 1962) \\
\hline Strategic apex & $\begin{array}{l}\text { "The strategic apex is charged with ensuring that the organization serve its mission in an effective way, } \\
\text { and also that it serve the needs of those people who control or otherwise have power over the } \\
\text { organization" (p. 25) } \\
\text { Comment: } \\
\text { - The link between the strategic apex and the CHQ explicated for the divisionalized form as: "the } \\
\text { structural relationship between the headquarters and the divisions, in effect between the strategic } \\
\text { apex and the top of the middle line" (p. 381); } \\
\text { Depending on the scope of the definition, two other parts (technostructure and support staff) can, to } \\
\text { some extent, also be considered the CHQ. }\end{array}$ & (Mintzberg, 1979) \\
\hline Corporation & "refers to the parent organization which owns several business units." (p. 14) & $\begin{array}{l}\text { (Yavitz \& Newman, } \\
\text { 1982) }\end{array}$ \\
\hline $\begin{array}{l}\text { Central administrative } \\
\text { office }\end{array}$ & $\begin{array}{l}\text { "the functions of employees include general company policy determination, planning, and management } \\
\text { (i.e., company purchasing, accounting, general engineering, direction of company personnel matters, and } \\
\text { legal and patent matters)." (p. 20) }\end{array}$ & (Montague, 1986) \\
\hline Corporate center & "the apparatus of CEO and other top managers, plus the staff advising them" (p. 128) & (Hansen \& Peytz, 1991) \\
\hline Corporate headquarters & $\begin{array}{l}\text { "include corporate directors, central functions such as finance and personnel, and other staff functions that } \\
\text { coordinate across business operations" (p. 4) } \\
\text { "Focused on: } \\
\text { - provide advice, information, guidance or other services to the parent company or to the business units, } \\
\text { - do not primarily trade with outside customers or clients, } \\
\text { - report directly to the CHQ, rather than to business units or intermediate management levels" (p. 4) }\end{array}$ & (Young \& Goold, 1993) \\
\hline $\begin{array}{l}\text { Corporate parent (parent } \\
\text { organization) }\end{array}$ & $\begin{array}{l}\text { Comment: no explicit definition but identifies five categories of a parent organization: (1) mental maps; (2) } \\
\text { corporate structures, systems, and processes; (3) central functions, services, and resources; (4) nature, } \\
\text { experience and skills (people); and (5) decentralization contract. (p. 124) }\end{array}$ & (Campbell et al., 1995a) \\
\hline Corporate parent & $\begin{array}{l}\text { "The corporate parent consists of all managers and staff not assigned to a business unit, including not only } \\
\text { the corporate headquarters but also division, group, region and other intermediate levels of management." } \\
\text { (p. 80) }\end{array}$ & $\begin{array}{l}\text { (Campbell et al., } \\
\text { 1995b) }\end{array}$ \\
\hline
\end{tabular}




\begin{tabular}{|c|c|c|}
\hline Term & Definition & Source \\
\hline Corporate headquarters & $\begin{array}{l}\text { "a corporate hierarchy of line managers and staff outside these businesses, called the 'corporate } \\
\text { headquarters' (CHQ). Generally, the CHQ includes functions that coordinate activities across business } \\
\text { units. I here follow Chandler (1994) (but not Young and Goold, 1993) in thinking of the CHQ as also } \\
\text { including top-level management." (p. 313) }\end{array}$ & (Foss, 1997) \\
\hline Corporate centre & "the physical corporate centre as a part of the home base or corporate parent." (p. 142) & $\begin{array}{l}\text { (Baaij, Van Den Bosch } \\
\& \text { Volberda, 2004) }\end{array}$ \\
\hline $\begin{array}{l}\text { Headquarters and } \\
\text { corporate headquarters }\end{array}$ & $\begin{array}{l}\text { "the HQ as having two essential elements: a top management group that typically has an official location } \\
\text { at which it meets, and a series of HQ functions that have the formal responsibility for fulfilling the roles } \\
\text { discussed above (treasury, investor relations, corporate communications etc.), each one of which has an } \\
\text { identifiable physical location. There is also a third element in the case of the corporate HQ (but not the } \\
\text { business unit HQ), namely the legal domicile- the registration of the MNC in a particular sovereign } \\
\text { nation, under which all the other legal entities that make up the MNC can be grouped." (p. 684) }\end{array}$ & $\begin{array}{l}\text { (Birkinshaw et al., } \\
\text { 2006) }\end{array}$ \\
\hline $\begin{array}{l}\text { Central administrative } \\
\text { office }\end{array}$ & $\begin{array}{l}\text { "administrative units including headquarters, which process information both within and between firms." } \\
\text { (p. 480) }\end{array}$ & $\begin{array}{l}\text { (Aarland, Davis, } \\
\text { Henderson \& Ono, } \\
\text { 2007) }\end{array}$ \\
\hline Corporate headquarters & $\begin{array}{l}\text { "staff functions and executive management with responsibility for, or providing services to, the whole of } \\
\text { (or most of) the company, excluding staff employed in divisional headquarters." (p. 385) }\end{array}$ & (Collis et al., 2007) \\
\hline $\begin{array}{l}\text { Central administrative } \\
\text { office }\end{array}$ & $\begin{array}{l}\text { "These facilities [...] produce services that are consumed by the operating units and plants of their firms. } \\
\text { Examples include strategic planning, business, financial and resource planning, as well as centralized } \\
\text { ancillary, administrative services such as legal, accounting, and the like. Some of these services may be } \\
\text { out-sourced, given out-sourcing is also a central function of HQ's." (p. 446) }\end{array}$ & $\begin{array}{l}\text { (Davis \& Henderson, } \\
\text { 2008) }\end{array}$ \\
\hline Corporate headquarters & $\begin{array}{l}\text { "[...] various departments at headquarters frame policies, develop programs, and make key strategic, } \\
\text { budgeting, pricing, and marketing decisions that shape the field organization's priorities, behavior, and } \\
\text { actions." (p. 108) }\end{array}$ & $\begin{array}{l}\text { (Garvin \& Levesque, } \\
\text { 2008) }\end{array}$ \\
\hline Headquarters & $\begin{array}{l}\text { "[...] process information within the firm and between firms, provide service functions for the firm such as } \\
\text { advertising, accounting and legal services, and co-ordinate and administer a variety of plant level activities } \\
\text { within the firm. Sometimes firms, especially bigger firms, spatially separate administrative functions from } \\
\text { production activity and create stand-alone HQs." (p. 431) }\end{array}$ & $\begin{array}{l}\text { (Henderson \& Ono, } \\
\text { 2008) }\end{array}$ \\
\hline Headquarters & $\begin{array}{l}\text { "Headquarters are defined as a management center and are strictly different from a plant. More } \\
\text { specifically, in our database a headquarters corresponds to a center of a firm's operations, administration } \\
\text { and marketing activity. This general definition of headquarters encompasses regional managerial centers } \\
\text { and may include sales offices. }{ }^{12} \text { A firm may have several headquarters [...]. } \\
{ }^{12} \text { This broad definition of headquarters is adequate for our work as regional headquarters as well as sales } \\
\text { offices have similar inputs requirements than central headquarters in term of labor, business services or } \\
\text { information. Their relocation across cities has similar implications on employment or economic activity } \\
\text { than the relocation of central headquarters." (p. 170) }\end{array}$ & $\begin{array}{l}\text { (Strauss-Kahn \& Vives, } \\
\text { 2009) }\end{array}$ \\
\hline
\end{tabular}




\section{APPENDIX 2}

\section{Identification Approach of the Publications Included in the Review}

\begin{tabular}{|c|c|c|c|c|}
\hline Journals* & $\begin{array}{c}\text { Step 1 } \\
\text { Keyword search in titles, } \\
\text { subject terms, abstracts }\end{array}$ & $\begin{array}{c}\text { Step } 2 \\
\text { Screening of articles } \\
\text { (reduced step 1 numbers) }\end{array}$ & $\begin{array}{c}\text { Step } 3 \\
\text { Back- \& forward search; } \\
\text { forthcoming articles }\end{array}$ & $\begin{array}{c}\text { Total } \\
\text { Sum of step } 2 \text { and step } 3 \\
\text { numbers }\end{array}$ \\
\hline \multicolumn{5}{|l|}{ Academic journals } \\
\hline AMJ & 12 & 8 & 3 & 11 \\
\hline AMR & - & - & - & - \\
\hline ASQ & 2 & - & - & - \\
\hline JIBS & 23 & 9 & 2 & 11 \\
\hline JMS & 1 & 1 & 2 & 3 \\
\hline JOM & 1 & - & - & - \\
\hline SMJ & 39 & 9 & $5 * *$ & 14 \\
\hline Others & $\mathrm{n} / \mathrm{a}$ & $\mathrm{n} / \mathrm{a}$ & 15 & 15 \\
\hline \multicolumn{5}{|c|}{ Practice-oriented journals } \\
\hline CMR & 7 & 3 & - & 3 \\
\hline HBR & 60 & 16 & 2 & 18 \\
\hline LRP & 31 & 16 & 1 & 17 \\
\hline SMR & 11 & 2 & - & 2 \\
\hline \multicolumn{5}{|l|}{ Others } \\
\hline Book (chapters) & $\mathrm{n} / \mathrm{a}$ & $\mathrm{n} / \mathrm{a}$ & 4 & 4 \\
\hline Total & 187 & 65 & 33 & 98 \\
\hline
\end{tabular}

AMJ = Academy of Management Journal; AMR = Academy of Management Review; ASQ = Administrative Science Quarterly; CMR = California Management Review; HBR = Harvard Business Review; JIBS = Journal of International Business Studies; JMS = Journal of Management Studies; JOM = Journal of Management; LRP = Long Range Planning; SMR = MIT Sloan Management Review; SMJ = Strategic Management Journal.

* Please note that some of the journals were founded later than the beginning of the search period (e.g., SMJ in 1980).

** Includes two forthcoming articles: Kleinbaum \& Stuart (2013), Nell \& Ambos (2013). 
Sample of Publications by Journals and Years

\begin{tabular}{|c|c|c|c|c|c|c|c|c|c|c|c|}
\hline \multirow[b]{2}{*}{$\underline{\text { Years* }}$} & \multicolumn{5}{|c|}{ Academic management journals } & \multicolumn{5}{|c|}{ Practice-oriented journals (incl. books) } & \multirow[b]{2}{*}{$\underline{\text { Total }}$} \\
\hline & AMJ & JIBS & $\underline{\mathrm{JMS}}$ & $\underline{\text { SMJ }}$ & Others & CMR & HBR & $\underline{\mathrm{LRP}}$ & $\underline{\text { SMR }}$ & Others & \\
\hline $1962-69$ & 1 & - & - & - & - & 2 & 3 & 1 & - & 1 & 8 \\
\hline $1970-79$ & 1 & 1 & - & - & 1 & - & 1 & - & - & - & 4 \\
\hline $1980-89$ & 4 & 2 & 1 & 2 & 1 & - & 2 & 2 & - & 1 & 15 \\
\hline 1990-99 & 2 & 1 & 1 & 3 & 5 & 1 & 4 & 9 & - & 1 & 27 \\
\hline 2000-09 & 3 & 3 & - & 5 & 2 & - & 8 & 5 & - & 1 & 27 \\
\hline $2010-12 * *$ & - & 4 & 1 & $4 * *$ & 6 & - & - & - & 2 & - & 17 \\
\hline Total & 11 & 11 & 3 & 14 & 15 & 3 & 18 & 17 & 2 & 4 & 98 \\
\hline
\end{tabular}

AMJ = Academy of Management Journal; CMR = California Management Review; HBR = Harvard Business Review; JIBS = Journal of International Business Studies; JMS = Journal of Management Studies; LRP = Long Range Planning; SMR = MIT Sloan Management Review; SMJ = Strategic Management Journal.

* Please note that some of the journals were founded later than the beginning of the search period (e.g., SMJ in 1980).

** Includes two forthcoming articles: Kleinbaum \& Stuart (2013), Nell \& Ambos (2013). 


\section{APPENDIX 3}

\section{Summary of CHQ Research (in Chronological Order)*}

\begin{tabular}{|c|c|c|c|c|}
\hline Author(s) (Year) & Focus & Theoretical Lens & Methodology & Key Findings related to the CHQ \\
\hline Chandler (1962) & $(1 ; 3-1)$ & $\begin{array}{l}\text { Organizational } \\
\text { contingency theory }\end{array}$ & $\begin{array}{l}\text { In-depth field } \\
\text { study of four cases } \\
\text { in the US }\end{array}$ & $\begin{array}{l}\text { The creation of the CHQ is contingent upon the adoption of the M-form } \\
\text { structure, and the CHQ has three duties: (1) coordination and integration of } \\
\text { the businesses' output, (2) centralized and specialized services, and ( } 3 \text { ) } \\
\text { present performance appraisals and future resource allocation. }\end{array}$ \\
\hline Balderston (1962) & $(1 ; 2-1 ; 3-1)$ & $\begin{array}{l}\text { Organization } \\
\text { theory (decision- } \\
\text { making schema) }\end{array}$ & $\begin{array}{l}\text { Mathematical } \\
\text { modeling/ } \\
\text { conceptual }\end{array}$ & $\begin{array}{l}\text { The CHQ has several duties: (1) self-maintenance activities of the CHQ, } \\
\text { and (2) allocation of resources to branches. The level of branch } \\
\text { standardization depends on the level of heterogeneity of local markets, and } \\
\text { the CHQ control mechanisms depend on the similarity of branches. }\end{array}$ \\
\hline Greenwood (1964) & $(1 ; 1-5)$ & $\begin{array}{l}\text { Organization } \\
\text { theory (no explicit } \\
\text { theoretical lens) }\end{array}$ & $\begin{array}{l}\text { Analysis of } 45 \mathrm{US} \\
\text { firms in } 16 \\
\text { industries }\end{array}$ & $\begin{array}{l}\text { The CHQ is responsible for corporate planning which helps: (1) spot } \\
\text { changes important to the firm's future; (2) ensure that internal operations are } \\
\text { in line with the long-term plans; (3) drawing up of short-term operating } \\
\text { plans based on the approved long-range plans. }\end{array}$ \\
\hline Murdick (1964) & (1) & $\begin{array}{l}\text { Managerial (no } \\
\text { explicit theoretical } \\
\text { lens) }\end{array}$ & $\begin{array}{l}\text { Conceptual/ } \\
\text { illustrative } \\
\text { examples }\end{array}$ & $\begin{array}{l}\text { The CHQ is responsible for corporate planning which is concerned with the } \\
\text { long run viability of the firm and important to develop a complete and } \\
\text { consistent set of policies and principles. }\end{array}$ \\
\hline Summers (1965) & $(1 ; 2-1 ; 4-1)$ & $\begin{array}{l}\text { Managerial (no } \\
\text { explicit theoretical } \\
\text { lens) }\end{array}$ & $\begin{array}{l}\text { Conceptual/ } \\
\text { illustrative } \\
\text { examples }\end{array}$ & $\begin{array}{l}\text { It is difficult for a central CHQ to pre-plan or transfer U.S. labor policies to } \\
\text { European markets because differences in labor relations between Common } \\
\text { Market and American countries exist. }\end{array}$ \\
\hline Berg $(1969,1977)$ & $(1 ; 3-1)$ & $\begin{array}{l}\text { Organizational } \\
\text { contingency theory }\end{array}$ & $\begin{array}{l}\text { Field study of } 10 \\
\text { Fortune } 500 \text { firms }\end{array}$ & $\begin{array}{l}\text { Conglomerates and less diversified industrial firms have different } \\
\text { approaches toward the structure and role of the CHQ. The differences in the } \\
\text { role of the CHQ can be associated with differing growth patterns or } \\
\text { diversification strategies. }\end{array}$ \\
\hline Hanan (1969) & (1) & $\begin{array}{l}\text { Managerial (no } \\
\text { explicit theoretical } \\
\text { lens) }\end{array}$ & $\begin{array}{l}\text { Conceptual/ } \\
\text { illustrative } \\
\text { examples }\end{array}$ & $\begin{array}{l}\text { Firms may spin out CHQ service functions such as purchasing, personnel, } \\
\text { and sales management into subsidiary profit centers, which can sell services } \\
\text { internally and externally and make profit out of underutilized corporate } \\
\text { resources. }\end{array}$ \\
\hline Rutenberg (1969) & $(1 ; 2-1 ; 1-5)$ & $\begin{array}{l}\text { Managerial (no } \\
\text { explicit theoretical } \\
\text { lens) }\end{array}$ & Conceptual & $\begin{array}{l}\text { The roles of the CHQ in the MNC depend on the characteristics of the } \\
\text { international subsidiaries. Active CHQ must realize synergistic benefits of } \\
\text { multi-national co-ordination that exceed the behavioral costs of intervening } \\
\text { in the affairs of subsidiaries. }\end{array}$ \\
\hline
\end{tabular}




\begin{tabular}{|c|c|c|c|c|}
\hline Author(s) (Year) & Focus & Theoretical Lens & Methodology & Key Findings related to the CHQ \\
\hline McInnes (1971) & $(1 ; 2-1)$ & $\begin{array}{l}\text { Managerial/ } \\
\text { normative }\end{array}$ & $\begin{array}{l}\text { Survey of } 30 \text { US } \\
\text { multinational } \\
\text { manufacturing } \\
\text { firms }\end{array}$ & $\begin{array}{l}\text { Changes in a firm's operations from a predominately domestic base to a } \\
\text { multinational base lead to changes in its formal reporting and control } \\
\text { systems (comparison with other operating units, with historical results, or } \\
\text { with a budget) which should be considered a major undertaking. }\end{array}$ \\
\hline $\begin{array}{l}\text { Schollhammer } \\
\text { (1971) }\end{array}$ & $(4-1 ; 2-1)$ & $\begin{array}{l}\text { Organizational } \\
\text { contingency (no } \\
\text { explicit theoretical } \\
\text { lens) }\end{array}$ & $\begin{array}{l}\text { Survey of } 12 \text { large } \\
\text { US and European } \\
\text { MNC }\end{array}$ & $\begin{array}{l}\text { Despite certain similarities, US and European MNC differ in terms of: (1) } \\
\text { basic organizational orientation, (2) structure of the relationships between } \\
\text { the CHQ and its foreign operating units, (3) the degree of centr./decentral., } \\
\text { (4) the standardization of procedures, and (5) organizational flexibility. }\end{array}$ \\
\hline Parks (1974) & $(2-1(3))$ & $\begin{array}{l}\text { Managerial (no } \\
\text { explicit theoretical } \\
\text { lens) }\end{array}$ & $\begin{array}{l}\text { Conceptual/ } \\
\text { illustrative } \\
\text { examples; US- } \\
\text { based firms }\end{array}$ & $\begin{array}{l}\text { The structure of European HQ depends on the CHQ and the nature of its } \\
\text { European business; the choice of a location for European HQ; the corporate } \\
\text { CEO plays a key role in making this decision. }\end{array}$ \\
\hline $\begin{array}{l}\text { Bazzaz \& Grinyer } \\
(1981)\end{array}$ & $(1 ; 3-1)$ & $\begin{array}{l}\text { Planning (no } \\
\text { explicit theoretical } \\
\text { lens) }\end{array}$ & $\begin{array}{l}\text { Quant. and qual. } \\
\text { analysis of } 48 \\
\text { corp. planners' } \\
\text { interviews in UK }\end{array}$ & $\begin{array}{l}\text { The CHQ planning sub-units had increased in their size and scope since the } \\
\text { late 1960s. The extent of corporate planning varied between types of } \\
\text { companies, the number of staff correlates with company size. }\end{array}$ \\
\hline $\begin{array}{l}\text { Leontiades \& } \\
\text { Tezel (1981) }\end{array}$ & $(1 ; 3-1 ; 2-1)$ & $\begin{array}{l}\text { Organizational } \\
\text { contingency theory }\end{array}$ & $\begin{array}{l}\text { Survey of } 88 \text { large } \\
\text { US industrial firms }\end{array}$ & $\begin{array}{l}\text { The study focuses on the planning role of the CHQ (corporate and business } \\
\text { planning): corporate planning efforts increase with an increasing degree of } \\
\text { business portfolio diversification, but the intensity of corporate planning } \\
\text { does not depend on firm size. }\end{array}$ \\
\hline Stubbart (1982) & $(1 ; 1-5)$ & $\begin{array}{l}\text { Managerial/ } \\
\text { normative }\end{array}$ & $\begin{array}{l}\text { Interviews with } 12 \\
\text { organizations in } \\
1978\end{array}$ & $\begin{array}{l}\text { Firms do rarely change the corporate planning at their CHQ: The attitudes } \\
\text { of academics and business media, business success, the right staff relate to } \\
\text { stability; TMT changes, decentral. moves, resource cuts, the availability of } \\
\text { competent staff and alternatives (e.g. external forecasts) relate to change. }\end{array}$ \\
\hline Teece (1982) & $(1 ; 3-1)$ & $\begin{array}{l}\text { Transaction cost } \\
\text { economics }\end{array}$ & Conceptual & $\begin{array}{l}\text { Two different types of diversification, lateral (i.e. related) vs. conglomerate } \\
\text { (i.e. unrelated) diversification exist: While the former type demands the } \\
\text { exploitation of "commonalities" of physical capital and technical skills (by } \\
\text { the CHQ), the latter benefits from internal capital markets. }\end{array}$ \\
\hline $\begin{array}{l}\text { Yavitz \& Newman } \\
\text { (1982) }\end{array}$ & $(1 ; 4-1)$ & $\begin{array}{l}\text { Managerial (no } \\
\text { explicit theoretical } \\
\text { lens) }\end{array}$ & Conceptual & $\begin{array}{l}\text { While the CHQ roles depend on a firm's industry the CHQ may } \\
\text { "strengthen" its businesses in two ways: (1) provision of valuable resources } \\
\text { (e.g., low-cost capital, outstanding executives); and (2) central management } \\
\text { of synergies across the business portfolio (corporate R\&D and marketing). }\end{array}$ \\
\hline $\begin{array}{l}\text { MacMillan \& } \\
\text { Meshulach (1983) }\end{array}$ & $(1 ; 2-1)$ & $\begin{array}{l}\text { Normative/ } \\
\text { economic } \\
\text { investment theory }\end{array}$ & $\begin{array}{l}\text { Quant. analysis; } \\
248 \text { firms } 1970-76 \\
\text { and } 197 \text { firms } \\
1977-1980\end{array}$ & $\begin{array}{l}\text { As indicated by an analysis of patterns of investment in expansion and/or } \\
\text { replacement of equipment by strategic BUs of U.S. companies, investment } \\
\text { decisions are made at two levels: the business level and the corporate level } \\
\text { (investment decisions are ratified at the corporate level). }\end{array}$ \\
\hline
\end{tabular}




\begin{tabular}{|c|c|c|c|c|}
\hline Author(s) (Year) & Focus & Theoretical Lens & Methodology & Key Findings related to the CHQ \\
\hline $\begin{array}{l}\text { Hitt \& Ireland } \\
(1986)\end{array}$ & $(1-6(3))$ & $\begin{array}{l}\text { Organizational } \\
\text { contingency theory }\end{array}$ & $\begin{array}{l}\text { Quant. analysis; } \\
\text { survey of } 185 \text { large } \\
\text { US industrial firms }\end{array}$ & $\begin{array}{l}\text { Based on } 55 \text { distinctive competence activities categorized into eight major } \\
\text { CHQ functions, the relationship between CHQ competencies and } \\
\text { performance varies for different diversification strategies but not for } \\
\text { different corporate structures. }\end{array}$ \\
\hline $\begin{array}{l}\text { Goold \& Campbell } \\
\text { (1987) }\end{array}$ & $(1 ; 1-6(3))$ & $\begin{array}{l}\text { Control theory } \\
\text { (implicit) }\end{array}$ & $\begin{array}{l}\text { Qual. analysis; } \\
\text { field study of } 16 \\
\text { large successful } \\
\text { UK firms }\end{array}$ & $\begin{array}{l}\text { Eight different CHQ styles exists, three of them are most frequently applied: } \\
\text { strategic planning, strategic control, and financial control (distinguishing the } \\
\text { styles by the extent of planning influence and by the nature of the controls); } \\
\text { its success depends on firm-specific circumstances. }\end{array}$ \\
\hline Gupta (1987) & $(2-1 ; 1-6)$ & $\begin{array}{l}\text { Information- } \\
\text { processing theory }\end{array}$ & $\begin{array}{l}\text { Survey of } 58 \mathrm{BU} \\
\text { general managers } \\
\text { in } 8 \text { Fortune } 500 \\
\text { firms }\end{array}$ & $\begin{array}{l}\text { Three dimensions can characterize the CHQ-BU relations - (1) openness in } \\
\text { the CHQ-BU relations, (2) subjectivity in performance assessment, and ( } 3 \text { ) } \\
\text { decentralization - each of which influence BU effectiveness depending on } \\
\text { the BU's strategic mission and the competitive strategy. }\end{array}$ \\
\hline $\begin{array}{l}\text { Hitt \& Ireland } \\
(1987)\end{array}$ & $(1 ; 1-6)$ & $\begin{array}{l}\text { No explicit } \\
\text { theoretical lens }\end{array}$ & $\begin{array}{l}\text { Conceptual/ } \\
\text { illustrative } \\
\text { examples (large } \\
\text { US firms) }\end{array}$ & $\begin{array}{l}\text { Besides other ways (product markets, technologies, and managerial } \\
\text { dominant logic), the development and application of CHQ distinctive } \\
\text { competencies, which can be applied across all of the organization's } \\
\text { businesses, is a key way for competitive advantages for the entire firm. }\end{array}$ \\
\hline Hoskisson (1987) & $(3-1 ; 1-6)$ & $\begin{array}{l}\text { Organizational } \\
\text { contingency theory }\end{array}$ & $\begin{array}{l}\text { Longitudinal study } \\
\text { of } 62 \text { large US } \\
\text { industrial firms } \\
\text { (archival data) }\end{array}$ & $\begin{array}{l}\text { M-form impl. increases the perf. for unrelated diversifiers, decreases the } \\
\text { perf. of vertical integrators, results for related diversifiers are not significant. } \\
\text { CHQ managers in highly diversified firms may focus on efficiency, which } \\
\text { may result in difficulties in responding to opportunities in the market. }\end{array}$ \\
\hline Porter (1987) & $(1 ; 3-1)$ & $\begin{array}{l}\text { Industrial } \\
\text { organization/ } \\
\text { market-based view }\end{array}$ & $\begin{array}{l}\text { Archival data; } 33 \\
\text { large diversified } \\
\text { US firms; } \\
\text { illustrative cases }\end{array}$ & $\begin{array}{l}\text { There are four different concepts of corporate strategy - (1) portfolio } \\
\text { management, (2) restructuring, (3) transferring skills, and (4) sharing } \\
\text { activities - with varying implications for the roles and design of the CHQ. }\end{array}$ \\
\hline $\begin{array}{l}\text { Govindarajan } \\
\text { (1988) }\end{array}$ & $(1 ; 2-1)$ & $\begin{array}{l}\text { Contingency } \\
\text { theory }\end{array}$ & $\begin{array}{l}\text { Two surveys of } 24 \\
\text { parent companies } \\
\text { and their strategic } \\
\text { business units }\end{array}$ & $\begin{array}{l}\text { CHQ should use different administrative mechanisms (budget evaluative } \\
\text { style, decentralization, locus of control) to manage different business units. }\end{array}$ \\
\hline $\begin{array}{l}\text { Martinez \& Ricks } \\
\text { (1989) }\end{array}$ & $(2-1 ; 1-5(2))$ & $\begin{array}{l}\text { Resource- } \\
\text { dependence theory; } \\
\text { control theory }\end{array}$ & $\begin{array}{l}\text { Survey of } 115 \text { of } \\
\text { Mexican affiliates } \\
\text { of U.S.-based } \\
\text { MNC, } 1987\end{array}$ & $\begin{array}{l}\text { The CHQ influence over affiliate human resource decisions is positively } \\
\text { related to resource dependence. The affiliate importance, the nationality of } \\
\text { affiliate managers, and the type of ownership arrangement were also found } \\
\text { to affect parent influence, but to lesser extents than resource dependencies. }\end{array}$ \\
\hline Ohmae (1989) & $(2-1 ; 3-1 ; 4-1)$ & $\begin{array}{l}\text { Managerial/ } \\
\text { normative; } \\
\text { contingency theory } \\
\text { (implicit) }\end{array}$ & $\begin{array}{l}\text { Conceptual/ } \\
\text { illustrative } \\
\text { examples }\end{array}$ & $\begin{array}{l}\text { Globally operating firms cannot centralize all key decision; and thus, firms } \\
\text { should decompose the CHQ into several RHQ. In addition, corporations } \\
\text { should make sure their widespread managers have a shared identity, which } \\
\text { comes from instilling a shared set of values. }\end{array}$ \\
\hline
\end{tabular}




\begin{tabular}{|c|c|c|c|c|}
\hline Author(s) (Year) & Focus & Theoretical Lens & Methodology & Key Findings related to the CHQ \\
\hline $\begin{array}{l}\text { Greenwood, } \\
\text { Hinings, \& Brown } \\
(1990)\end{array}$ & $(1 ; 3-1)$ & Control theory & $\begin{array}{l}\text { Qual. and quant.; } \\
\text { large US } \\
\text { accounting firms }\end{array}$ & $\begin{array}{l}\text { Compared to M-form and holding companies, the CHQ in professional } \\
\text { partnerships }\left(\mathrm{P}^{2} \text {-form) differs along three control dimensions: strategic, }\right. \\
\text { market-financial and operating control. }\end{array}$ \\
\hline Chandler (1991) & $(1 ; 3-1 ; 2-1)$ & $\begin{array}{l}\text { Organizational } \\
\text { contingency theory }\end{array}$ & $\begin{array}{l}\text { Conceptual/ } \\
\text { illustrative cases } \\
\text { (IBM, GE, } \\
\text { DuPont) }\end{array}$ & $\begin{array}{l}\text { The CHQ performs two basic functions: (1) entrepreneurial (value-creation, } \\
\text { strategic planning) and (2) administrative (loss prevention, financial } \\
\text { control). In industries in which MBF have few advantages compared to } \\
\text { single business firms, the CHQ should perform financial controls only. }\end{array}$ \\
\hline Howard (1991) & $(1 ; 3-1)$ & $\begin{array}{l}\text { Managerial/ } \\
\text { normative }\end{array}$ & $\begin{array}{l}\text { Single case study } \\
\text { of Italian } \\
\text { manufacturer } \\
\text { Gruppo GFT }\end{array}$ & $\begin{array}{l}\text { The more the company penetrates global markets, the more it has to respond } \\
\text { to myriad local differences among those markets: The periphery has to } \\
\text { become the center of top management's attention; and the key role of the } \\
\text { CHQ managers is to manage the continuous redesign of the overall firm. }\end{array}$ \\
\hline Alexander (1992) & $(1 ; 3-1)$ & $\begin{array}{l}\text { Managerial/ } \\
\text { normative }\end{array}$ & $\begin{array}{l}\text { Conceptual/ } \\
\text { illustrative } \\
\text { examples }\end{array}$ & $\begin{array}{l}\text { The CHQ serves as an intermediate between shareholders and business unit } \\
\text { managers in a corporate portfolio. Beyond risk reduction, each CHQ needs } \\
\text { to define the potential scope of its role considering its particular corporate } \\
\text { capabilities to play this role. }\end{array}$ \\
\hline $\begin{array}{l}\text { Barton, Brown, } \\
\text { Cound, Marsh, \& } \\
\text { Willey (1992) }\end{array}$ & $(2-1)$ & Control theory & $\begin{array}{l}\text { Quant. analysis: } \\
\text { survey of } 100 \text { large } \\
\text { divisionalized UK } \\
\text { firms, } 1989\end{array}$ & $\begin{array}{l}\text { With respect to the role the parent company plays in the investment } \\
\text { decision-making process, the behavior of the CHQ could be leading to } \\
\text { internally generated short-termism, and myopic underinvestment in British } \\
\text { industry. }\end{array}$ \\
\hline $\begin{array}{l}\text { Hill, Hitt, \& } \\
\text { Hoskisson (1992) }\end{array}$ & $(1 ; 2-1 ; 1-6(3))$ & $\begin{array}{l}\text { Organizational } \\
\text { contingency theory }\end{array}$ & $\begin{array}{l}\text { Quant. analysis: } \\
\text { Survey of } 184 \\
\text { Fortune } 1,000 \\
\text { firms }\end{array}$ & $\begin{array}{l}\text { A fit between diversification strategy, organization structure, and CHQ } \\
\text { control systems explains superior performance. An organization design that } \\
\text { aims at exploitation of economies of scope needs cooperation between BUs } \\
\text { whereas efficient internal governance needs competition between BUs. }\end{array}$ \\
\hline $\begin{array}{l}\text { Roth \& Nigh } \\
\text { (1992) }\end{array}$ & $(1-2 ; 1-5(2))$ & $\begin{array}{l}\text { Transaction cost } \\
\text { economics }\end{array}$ & $\begin{array}{l}\text { Survey of } 105 \\
\text { foreign } \\
\text { subsidiaries in the } \\
\text { US }\end{array}$ & $\begin{array}{l}\text { An analysis of the effectiveness of the CHQ-subsidiaries relationship } \\
\text { reveals that coordination of primary activities and personal integrating } \\
\text { mechanisms (i.e. behavioral control) positively influence the effectiveness } \\
\text { of the CHQ-subsidiary relationship, while conflict affects it negatively. }\end{array}$ \\
\hline Russo (1992) & $(2-1 ; 1-6(2) ; 4-1)$ & $\begin{array}{l}\text { Transaction cost } \\
\text { economics }\end{array}$ & $\begin{array}{l}\text { Quant. analysis: } \\
\text { subsidiaries of } 54 \\
\text { US electric utilities } \\
1966-86\end{array}$ & $\begin{array}{l}\text { There is a connection between the characteristics of the regulated parent } \\
\text { company and subsidiary performance. Intense regulatory oversight } \\
\text { negatively affects new venture performance. }\end{array}$ \\
\hline Hungenberg (1993) & $(1 ; 2-1)$ & $\begin{array}{l}\text { Managerial (no } \\
\text { explicit theoretical } \\
\text { lens) }\end{array}$ & $\begin{array}{l}\text { Conceptual/ } \\
\text { illustrative case } \\
\text { (Daimler-Benz) }\end{array}$ & $\begin{array}{l}\text { The CHQ adds value by defining the business portfolio and by coordinating } \\
\text { the businesses. The CHQ role and several moderating factors influence the } \\
\text { intensity of CHQ intervention in the decision-making process at the } \\
\text { business level and the extent of cross-business coordination. }\end{array}$ \\
\hline
\end{tabular}




\begin{tabular}{|c|c|c|c|c|}
\hline Author(s) (Year) & Focus & Theoretical Lens & Methodology & Key Findings related to the CHQ \\
\hline $\begin{array}{l}\text { Markides \& } \\
\text { Williamson (1994) }\end{array}$ & $(1 ; 2-1 ; 1-6(2))$ & $\begin{array}{l}\text { Resource-based } \\
\text { view }\end{array}$ & $\begin{array}{l}\text { Quant. analysis: } \\
164 \text { Fortune } 500 \\
\text { firms }\end{array}$ & $\begin{array}{l}\text { Firms with CHQ that enable sharing of similar opportunities (related to } \\
\text { brand building, marketing and channel management, process skills in } \\
\text { customization, and management of skilled teams) profit from related } \\
\text { diversification. }\end{array}$ \\
\hline $\begin{array}{l}\text { Berger \& Ofek } \\
(1995)\end{array}$ & $(1 ; 1-6(3))$ & $\begin{array}{l}\text { Financial } \\
\text { economics } \\
\text { (efficient market } \\
\text { hypothesis) }\end{array}$ & $\begin{array}{l}\text { Longitudinal study } \\
\text { of 3,659 US firms } \\
(1986-91, \text { archival } \\
\text { data) }\end{array}$ & $\begin{array}{l}\text { Diversification reduces the value of the MBF by } 13-15 \% \text { on average, } \\
\text { independent of firm size and less for related diversifying firms. The value } \\
\text { loss can be partly attributed to the CHQ, since overinvestment and cross- } \\
\text { subsidization is related to value reduction, partly mitigated by tax benefits. }\end{array}$ \\
\hline Campbell (1995) & $(2-1(3))$ & $\begin{array}{l}\text { Managerial/ } \\
\text { normative } \\
\text { (parenting theory) }\end{array}$ & $\begin{array}{l}\text { Qualitative/ } \\
\text { illustrative; } 15 \\
\text { firms (e.g., GE, } \\
\text { Canon, 3M, Shell) } \\
\end{array}$ & $\begin{array}{l}\text { Three conditions are needed for vertical integration strategy: (1) the BU } \\
\text { must have the potential to improve its performance or its relationship with } \\
\text { sister companies; (2) the CHQ must possess the skills or resources necessary } \\
\text { to help the BU; (3) the CHQ must understand the business well enough. }\end{array}$ \\
\hline $\begin{array}{l}\text { Campbell, Goold, } \\
\text { \& Alexander } \\
\text { (1995a) }\end{array}$ & $(1 ; 2-1)$ & $\begin{array}{l}\text { Managerial/ } \\
\text { normative } \\
\text { (parenting theory) }\end{array}$ & $\begin{array}{l}\text { Conceptual, } \\
\text { illustrative cases }\end{array}$ & $\begin{array}{l}\text { Instead of looking at how businesses relate to one another, the CHQ should } \\
\text { look at how well its skills fit its businesses' needs and whether owning them } \\
\text { creates or destroys value. }\end{array}$ \\
\hline $\begin{array}{l}\text { Campbell, Goold, } \\
\text { \& Alexander } \\
(1995 b)\end{array}$ & $(1 ; 1-6)$ & $\begin{array}{l}\text { Managerial/ } \\
\text { normative } \\
\text { (parenting theory) }\end{array}$ & $\begin{array}{l}\text { Conceptual/ } \\
\text { illustrative cases } \\
\text { (ABB, Canon, } \\
\text { Emerson) }\end{array}$ & $\begin{array}{l}\text { The CHQ can add (or destroy) value in four different ways: (1) stand-alone } \\
\text { influence (impact on strategy of each business), (2) linkage influence } \\
\text { (fostering cooperation among businesses), (3) central functions and services, } \\
\text { and (4) corporate development (acquisitions, alliances etc.). }\end{array}$ \\
\hline $\begin{array}{l}\text { Ferlie \& Pettigrew } \\
(1996)\end{array}$ & $(1 ; 1-5)$ & Multiple theories & Conceptual review & $\begin{array}{l}\text { CHQ level change appears as an increasingly important phenomenon in the } \\
\text { late } 1980 \text { s and early 1990s. }\end{array}$ \\
\hline Goold (1996a) & $(1 ; 1-5)$ & $\begin{array}{l}\text { Managerial/ } \\
\text { normative } \\
\text { (parenting theory) }\end{array}$ & $\begin{array}{l}\text { Conceptual; } \\
\text { qualitative analysis } \\
\text { of several cases }\end{array}$ & $\begin{array}{l}\text { A focus on opportunities to add value, and on distinctive resources } \\
\text { possessed by the CHQ that lead to added value, provides the basis for valid } \\
\text { corporate strategies. }\end{array}$ \\
\hline Goold (1996b) & $(1 ; 1-5(2))$ & $\begin{array}{l}\text { Managerial/ } \\
\text { normative } \\
\text { (parenting theory) }\end{array}$ & $\begin{array}{l}\text { Conceptual; } \\
\text { qualitative analysis } \\
\text { of several cases }\end{array}$ & $\begin{array}{l}\text { Instead of paying less attention and providing fewer resources, the CHQ } \\
\text { should develop a more constructive, added-value relationship with the } \\
\text { mature businesses in the portfolio focused on lean operations, capacity } \\
\text { closure, influencing investment decision, price and margin, rejuvenation. }\end{array}$ \\
\hline $\begin{array}{l}\text { Markides \& } \\
\text { Williamson (1996) }\end{array}$ & $(3-1 ; 2-1 ; 1-6(3))$ & $\begin{array}{l}\text { Resource-based } \\
\text { view }\end{array}$ & $\begin{array}{l}\text { Quant. analysis: } \\
\text { survey of } 136 \text { large } \\
\text { US firms }\end{array}$ & $\begin{array}{l}\text { Strategies of related diversification are beneficial only when the CHQ grants } \\
\text { the businesses preferential access to strategic assets. Competences to } \\
\text { develop new strategic assets faster and more efficiently than competitors are } \\
\text { a source of long-term superior performance. }\end{array}$ \\
\hline
\end{tabular}




\begin{tabular}{|c|c|c|c|c|}
\hline Author(s) (Year) & Focus & Theoretical Lens & Methodology & Key Findings related to the CHQ \\
\hline $\begin{array}{l}\text { Tan \& Vertinsky } \\
\text { (1996) }\end{array}$ & $(1 ; 1-5)$ & $\begin{array}{l}\text { Internationalizatio } \\
\mathrm{n} \text { theory }\end{array}$ & $\begin{array}{l}\text { Quant. analysis: } \\
\text { survey of } 262 \\
\text { Japanese } \\
\text { electronics firms }\end{array}$ & $\begin{array}{l}\text { Size and financial capabilities, as well as possession of knowledge-based, } \\
\text { firm-specific strategic assets, are significantly related to early FDI. } \\
\text { Specifically, CHQ attributes that facilitate market intelligence capabilities } \\
\text { permit early recognition of investment opportunities }\end{array}$ \\
\hline $\begin{array}{l}\text { Collis \& } \\
\text { Montgomery } \\
(1997)\end{array}$ & (1) & $\begin{array}{l}\text { Resource-based } \\
\text { view }\end{array}$ & $\begin{array}{l}\text { Conceptual/ } \\
\text { illustrative cases }\end{array}$ & $\begin{array}{l}\text { The CHQ perform four roles: (1) formulate and communicate a firm's } \\
\text { strategy, (2) allocate of valuable resources, ( } 3 \text { ) fulfill general overhead } \\
\text { functions, and (4) set administrative context by choosing structure, systems, } \\
\text { and control processes and by achieving coherence. }\end{array}$ \\
\hline Foss (1997) & $(1 ; 2-1)$ & $\begin{array}{l}\text { Resource-based } \\
\text { view; transaction } \\
\text { cost economics }\end{array}$ & $\begin{array}{l}\text { Conceptual/ } \\
\text { deductive theory- } \\
\text { building }\end{array}$ & $\begin{array}{l}\text { The CHQ should perform two mechanisms: (1) knowledge-direction } \\
\text { ('initiating intra-firm learning processes') and (2) the exploitation of } \\
\text { 'flexibility' (e.g., altering responsibilities of business managers, } \\
\text { changing/coordinating the business portfolio). }\end{array}$ \\
\hline $\begin{array}{l}\text { Collis \& } \\
\text { Montgomery } \\
(1998)\end{array}$ & $(1 ; 2-1 ; 3-1)$ & $\begin{array}{l}\text { Resource-based } \\
\text { view }\end{array}$ & $\begin{array}{l}\text { Conceptual; } \\
\text { illustrative cases } \\
\text { (Newell, Sharp, } \\
\text { Tyco) }\end{array}$ & $\begin{array}{l}\text { Firms should tailor organizational structures and systems to the needs of } \\
\text { their particular strategy instead of creating plain-vanilla CHQs and } \\
\text { infrastructures. }\end{array}$ \\
\hline Pettifer (1998) & $(1 ; 1-6)$ & $\begin{array}{l}\text { Managerial/ } \\
\text { normative }\end{array}$ & $\begin{array}{l}\text { Conceptual/ } \\
\text { illustrative } \\
\text { examples }\end{array}$ & $\begin{array}{l}\text { Three different types of CHQ activities require diverse performance } \\
\text { measures: (1) core activities are mostly predictable, repetitive and can be } \\
\text { benchmarked; (2) added value activities are less repetitive and less } \\
\text { benchmarkable; (3) shared services targeted to cover their cost of capital. }\end{array}$ \\
\hline Scharfstein (1998) & $(1 ; 2-1(3))$ & $\begin{array}{l}\text { Financial } \\
\text { economics } \\
\text { (efficient market } \\
\text { hypothesis) }\end{array}$ & $\begin{array}{l}\text { Longitudinal study } \\
\text { of } 165 \text { US } \\
\text { conglomerates, } \\
1979-94\end{array}$ & $\begin{array}{l}\text { Indicating agency problems between the CHQ and investors, especially } \\
\text { firms in which the management has small equity stakes, highly diversified } \\
\text { firms tend to overinvest in businesses with poor investment prospects and } \\
\text { tend to underinvest in those with promising investment prospects. }\end{array}$ \\
\hline Young (1998a) & $(1 ; 2-1 ; 2)$ & $\begin{array}{l}\text { Managerial/ } \\
\text { normative }\end{array}$ & $\begin{array}{l}\text { Conceptual; survey } \\
\text { based data }\end{array}$ & $\begin{array}{l}\text { The number of CHQ staff and functions depends on the role of the CHQ. } \\
\text { Corporate managers find it easier to add value if the businesses in their } \\
\text { portfolios have similar products, produced using similar technologies and } \\
\text { sold to similar customer bases. }\end{array}$ \\
\hline Campbell (1999) & $(1 ; 1-5)$ & $\begin{array}{l}\text { Managerial/ } \\
\text { normative }\end{array}$ & $\begin{array}{l}\text { Conceptual/ } \\
\text { illustrative cases } \\
\text { (Granada, Dow, } \\
\text { Emerson) }\end{array}$ & $\begin{array}{l}\text { The CHQ can destroy value by poor corporate planning (it can cause } \\
\text { business professionals to waste time and money, send the wrong signals to } \\
\text { managers, and lead managers to follow bad advice) and CHQ staff must } \\
\text { thus manage their involvement carefully. }\end{array}$ \\
\hline Kono (1999) & $(1 ; 3-1)$ & $\begin{array}{l}\text { Organizational } \\
\text { contingency theory }\end{array}$ & $\begin{array}{l}\text { Quant. analysis: } \\
\text { survey of } 97 \\
\text { Japanese firms }\end{array}$ & $\begin{array}{l}\text { The CHQ has three functions: (1) development of the corporate strategy, (2) } \\
\text { expert staff assistance to develop strong core competencies, and (3) } \\
\text { providing centralized services; related diversifiers tend to have larger CHQ } \\
\text { than in unrelated firms. }\end{array}$ \\
\hline
\end{tabular}




\begin{tabular}{|c|c|c|c|c|}
\hline Author(s) (Year) & Focus & Theoretical Lens & Methodology & Key Findings related to the CHQ \\
\hline $\begin{array}{l}\text { Scharfstein \& Stein } \\
(2000)\end{array}$ & $(1 ; 1-5(2))$ & $\begin{array}{l}\text { Financial } \\
\text { economics } \\
\text { (efficient market } \\
\text { hypothesis) }\end{array}$ & Theory-building & $\begin{array}{l}\text { A two-tiered agency model shows how BU managers' rent-seeking behavior } \\
\text { can subvert the internal capital market: By rent-seeking, BU managers can } \\
\text { raise their bargaining power and extract greater compensation from the CEO } \\
\text { which may take the form of preferential capital budgeting allocations. }\end{array}$ \\
\hline $\begin{array}{l}\text { Van Oijen \& } \\
\text { Douma (2000) }\end{array}$ & $(1 ; 1-6(2))$ & $\begin{array}{l}\text { Organizational } \\
\text { contingency theory }\end{array}$ & $\begin{array}{l}\text { Quant. analysis: } \\
\text { Survey of } 67 \text { listed } \\
\text { Dutch firms }\end{array}$ & $\begin{array}{l}\text { High performing MBFs have a better fit between the diversification strategy } \\
\text { and the CHQ roles than low performing MBFs because they align the } \\
\text { planning, evaluation, selection, motivation, and support roles with the } \\
\text { diversification strategy, however, not job rotation and coordination. }\end{array}$ \\
\hline $\begin{array}{l}\text { Birkinshaw \& } \\
\text { Hood (2001) }\end{array}$ & $(1-5(2))$ & $\begin{array}{l}\text { Managerial/ } \\
\text { normative }\end{array}$ & $\begin{array}{l}\text { Qualitative } \\
\text { analysis; more than } \\
50 \text { MNCs }\end{array}$ & $\begin{array}{l}\text { Formal and informal communication channels between CHQ and } \\
\text { subsidiaries are critical for innovation: CHQ should provide seed money; } \\
\text { use formal requests to increase demand for seed money; encourage } \\
\text { subsidiaries to be incubators for fledgling businesses; build int. networks. }\end{array}$ \\
\hline $\begin{array}{l}\text { Darragh \& } \\
\text { Campbell (2001) }\end{array}$ & $(1-5)$ & $\begin{array}{l}\text { Managerial (no } \\
\text { explicit theoretical } \\
\text { lens) }\end{array}$ & $\begin{array}{l}\text { Qualitative } \\
\text { analysis of } 28 \\
\text { corporate } \\
\text { initiatives }\end{array}$ & $\begin{array}{l}\text { While corporate initiatives are the main vehicle through which the CHQ } \\
\text { creates additional value in its portfolio of businesses, many of them become } \\
\text { stuck. Nine root causes can help diagnose why a corporate initiatives has } \\
\text { become stuck. }\end{array}$ \\
\hline $\begin{array}{l}\text { Goold, Pettifer, \& } \\
\text { Young (2001) }\end{array}$ & (1) & $\begin{array}{l}\text { Managerial (no } \\
\text { explicit theoretical } \\
\text { lens) }\end{array}$ & $\begin{array}{l}\text { Conceptual/ } \\
\text { descriptive survey } \\
\text { results/ illustrative } \\
\text { cases }\end{array}$ & $\begin{array}{l}\text { Three different CHQ roles exist: (1) minimum CHQ (legal and regulatory } \\
\text { obligations), (2) value-added CHQ (influence on businesses, closely related } \\
\text { to corporate strategy), and ( } 3 \text { ) shared services, each of which need } \\
\text { competencies and allows justification for the existence of certain CHQ staff. }\end{array}$ \\
\hline $\begin{array}{l}\text { Jacque \& Vaaler } \\
\text { (2001) }\end{array}$ & $(4-1 ; 1-6(4))$ & $\begin{array}{l}\text { Agency theory/ } \\
\text { control theory }\end{array}$ & Conceptual & $\begin{array}{l}\text { In order to avoid principle-agent problems between CHQ and subsidiaries } \\
\text { due to exchange rate fluctuations, economic value added can be used to } \\
\text { assess foreign subsidiary performance in emerging-market countries in the } \\
\text { presence of unexpected, exchange-related shocks. }\end{array}$ \\
\hline $\begin{array}{l}\text { Raynor \& Bower } \\
(2001)\end{array}$ & $(1 ; 2-1(4))$ & $\begin{array}{l}\text { Managerial/ } \\
\text { normative (no } \\
\text { explicit theoretical } \\
\text { lens) }\end{array}$ & $\begin{array}{l}\text { Conceptual/ four } \\
\text { illustrative cases } \\
\text { (Sprint, WPP, } \\
\text { Teradyne, Viacom) }\end{array}$ & $\begin{array}{l}\text { The CHQ should be more directive in turbulent markets and must play an } \\
\text { active role in defining the scope of division-level strategy. Firms should } \\
\text { adopt a dynamic approach to cooperation among BUs, enabling varying } \\
\text { degrees of relatedness between BUs depending on strategic circumstances. }\end{array}$ \\
\hline Batten (2002) & $(1-5)$ & $\begin{array}{l}\text { Managerial/ } \\
\text { resource-based } \\
\text { view (no explicit } \\
\text { theoretical lens) }\end{array}$ & $\begin{array}{l}\text { Illustrative case } \\
\text { study }\end{array}$ & $\begin{array}{l}\text { The CHQ's attitude and resources (e.g., capital, management talent, and } \\
\text { experience in related fields) is critical for successful corporate } \\
\text { entrepreneurship. }\end{array}$ \\
\hline $\begin{array}{l}\text { Goold \& Campbell } \\
(2002 \mathrm{a})\end{array}$ & $(3-1 ; 1-5(3))$ & $\begin{array}{l}\text { Managerial/ } \\
\text { normative } \\
\text { (parenting theory) }\end{array}$ & $\begin{array}{l}\text { Conceptual; } \\
\text { illustrative cases }\end{array}$ & $\begin{array}{l}\text { A systematic approach (nine tests) should be used to evaluate an existing } \\
\text { organization design or create a new one. The tests help the CHQ' managers } \\
\text { create parenting advantage. }\end{array}$ \\
\hline
\end{tabular}




\begin{tabular}{|c|c|c|c|c|}
\hline Author(s) (Year) & Focus & Theoretical Lens & Methodology & Key Findings related to the CHQ \\
\hline $\begin{array}{l}\text { Goold \& Campbell } \\
(2002 b)\end{array}$ & $(1 ; 3-1)$ & $\begin{array}{l}\text { Managerial/ } \\
\text { normative } \\
\text { (parenting theory) }\end{array}$ & $\begin{array}{l}\text { Qualitative } \\
\text { analysis of large } \\
\text { companies and } \\
\text { smaller firms }\end{array}$ & $\begin{array}{l}\text { There are some special parenting challenges in complex structures, but the } \\
\text { quest for 'parenting advantage' should remain a fundamental driver of } \\
\text { corporate strategy and structure. }\end{array}$ \\
\hline $\begin{array}{l}\text { Markides (2002, } \\
\text { 2006) }\end{array}$ & $(1)$ & $\begin{array}{l}\text { Transaction costs; } \\
\text { learning }\end{array}$ & Conceptual & $\begin{array}{l}\text { The role of the CHQ is directly related to the economic rationale for the } \\
\text { existence of the MBF which is threefold: (1) exploit economies of scope, (2) } \\
\text { benefit from efficient internal capital markets, and (3) promote sharing of } \\
\text { knowledge across BUs to create new strategic assets. }\end{array}$ \\
\hline Song (2002) & $(1 ; 1-5(2))$ & $\begin{array}{l}\text { Capability-based } \\
\text { view }\end{array}$ & $\begin{array}{l}\text { Quant. analysis: } \\
\text { 128 Electronics } \\
\text { companies; Japan } \\
1988-94\end{array}$ & $\begin{array}{l}\text { In addition to the importance of capabilities at host country, and at local } \\
\text { subsidiary levels, CHQ capabilities play an important role in sequential } \\
\text { foreign investment decisions. }\end{array}$ \\
\hline $\begin{array}{l}\text { Adner \& Helfat } \\
(2003)\end{array}$ & $(1 ; 1-6(4))$ & $\begin{array}{l}\text { Dynamic } \\
\text { capabilities view }\end{array}$ & $\begin{array}{l}\text { Longitudinal study } \\
\text { of } 30 \text { US firms in } \\
\text { the petroleum } \\
\text { industry; } 1977-97\end{array}$ & $\begin{array}{l}\text { Differences in managerial decisions at the CHQ are partly responsible for } \\
\text { performance heterogeneity. Dynamic managerial capabilities at the CHQ } \\
\text { and their underlying attributes (human capital, social capital, and managerial } \\
\text { cognition) explain how CHQ managers cope with environmental changes. }\end{array}$ \\
\hline $\begin{array}{l}\text { Bowman \& } \\
\text { Ambrosini (2003) }\end{array}$ & $(1 ; 3-1)$ & $\begin{array}{l}\text { Dynamic } \\
\text { capabilities view }\end{array}$ & Conceptual & $\begin{array}{l}\text { Six CHQ resource creation configurations stem from six modes of CHQ } \\
\text { resource creation - (1) reconfig. of supp. activities, (2) reconfig. of core } \\
\text { processes, (3) leverage of existing resources, (4) encouraged learning, (5) } \\
\text { provoked learning, and (6) creative integration - and org. design parameters. }\end{array}$ \\
\hline $\begin{array}{l}\text { Miller \& Waller } \\
(2003)\end{array}$ & $(1 ; 1-5(2))$ & Real option theory & Conceptual & $\begin{array}{l}\text { Combining scenario planning and real option analysis in an integrated risk } \\
\text { management process helps CHQ managers consider the full range of } \\
\text { exposures across a firm's portfolio of businesses. }\end{array}$ \\
\hline $\begin{array}{l}\text { Kaplan \& Norton } \\
(2005)\end{array}$ & $(1 ; 1-5)$ & $\begin{array}{l}\text { Managerial (no } \\
\text { explicit theoretical } \\
\text { lens) }\end{array}$ & $\begin{array}{l}\text { Conceptual/ } \\
\text { illustrative } \\
\text { examples }\end{array}$ & $\begin{array}{l}\text { A corporate-level unit can help oversee all activities related to strategy (an } \\
\text { office of strategy management, OSM) and thus sustain a strategic focus. }\end{array}$ \\
\hline Stalk (2005) & $(1 ; 1-5)$ & $\begin{array}{l}\text { Managerial (no } \\
\text { explicit theoretical } \\
\text { lens) }\end{array}$ & $\begin{array}{l}\text { Conceptual/ } \\
\text { illustrative } \\
\text { examples }\end{array}$ & $\begin{array}{l}\text { The CHQ should be lean, but not so small as to be ineffective. Active CHQ } \\
\text { can have a positive impact on subsidiaries, as they can see broader trends, } \\
\text { new competition and strategies that the smaller entities miss because they } \\
\text { are fixed on their own industry. }\end{array}$ \\
\hline Thurm (2005) & $(1 ; 3-1)$ & $\begin{array}{l}\text { Managerial/ } \\
\text { architectural (no } \\
\text { explicit theoretical } \\
\text { lens) }\end{array}$ & $\begin{array}{l}\text { Illustrative case } \\
\text { study of The New } \\
\text { York Times }\end{array}$ & $\begin{array}{l}\text { The CHQ building is an important firm' asset and reflects the firm's mission } \\
\text { and produces a truly energizing work environment. Firms should take an } \\
\text { active role when to make sure that the CHQ building reflects the firm's } \\
\text { identity. }\end{array}$ \\
\hline
\end{tabular}




\begin{tabular}{|c|c|c|c|c|}
\hline Author(s) (Year) & Focus & Theoretical Lens & Methodology & Key Findings related to the CHQ \\
\hline $\begin{array}{l}\text { Birkinshaw, } \\
\text { Braunerhjelm, } \\
\text { Holm, \& Terjesen } \\
(2006)\end{array}$ & $(1 ; 3-1 ; 4-1)$ & $\begin{array}{l}\text { Multinational } \\
\text { corporation } \\
\text { (MNC), multiple } \\
\text { theoretical lenses }\end{array}$ & $\begin{array}{l}\text { Quant.: survey of } \\
125 \text { BU HQ and } 35 \\
\text { CHQ of the largest } \\
\text { Swedish MNCs }\end{array}$ & $\begin{array}{l}\text { Firms relocate BU HQ and the CHQ for different reasons: Firms relocate } \\
\text { BU HQ overseas in response to changes in the internal configuration and } \\
\text { changing market demands; they relocate their CHQ in response to external } \\
\text { stakeholders' demands (international financial markets and shareholders). }\end{array}$ \\
\hline $\begin{array}{l}\text { Chan \& Makino } \\
(2007)\end{array}$ & $(1 ; 2-1(3) ; 2-1(4))$ & Institutional theory & $\begin{array}{l}\text { Quant.: } 898 \\
\text { Japanese MNCs, } \\
\text { 4,451 subs. in } 39 \\
\text { countr., } 1988-99\end{array}$ & $\begin{array}{l}\text { MNC subsidiary ownership choices are influenced by legitimacy rationales. } \\
\text { Specifically, MNCs are likely to take a higher ownership stake in response } \\
\text { to strong internal pressure to sustain their internal legitimacy at the } \\
\text { corporate level of their institutional environment. }\end{array}$ \\
\hline $\begin{array}{l}\text { Collis, Young, \& } \\
\text { Goold (2007) }\end{array}$ & $\begin{array}{l}(1 ; 3-1 ; 4-1 ; 1-5 ; 1- \\
6)\end{array}$ & $\begin{array}{l}\text { Organizational } \\
\text { contingency } \\
\text { theory, multiple } \\
\text { theoretical lenses }\end{array}$ & $\begin{array}{l}\text { Quant. analysis; } \\
\text { survey of } 467 \\
\text { firms in } 7 \\
\text { countries; } 1997-99\end{array}$ & $\begin{array}{l}\text { The size and structure of CHQs depends on firm size, corporate strategy, } \\
\text { and governance system and the fit between the CHQ and the corporate } \\
\text { strategy is critical for superior firm performance. }\end{array}$ \\
\hline $\begin{array}{l}\text { Bouquet \& } \\
\text { Birkinshaw (2008) }\end{array}$ & $(1-5(2))$ & $\begin{array}{l}\text { Attention-based } \\
\text { view }\end{array}$ & $\begin{array}{l}\text { Quant.: Survey of } \\
283 \text { foreign } \\
\text { subsidiaries of } \\
\text { large MNCs }\end{array}$ & $\begin{array}{l}\text { CHQ attention is partially based on the BUs' structural positions within a } \\
\text { corporate system, and BUs have a 'voice' that can be used to attract CHQ } \\
\text { attention, but this relationship is moderated by two specific aspects of the } \\
\text { BU's historical situation: geographic distance and downstream competence. }\end{array}$ \\
\hline $\begin{array}{l}\text { Garvin \& } \\
\text { Levesque (2008) }\end{array}$ & $(3-1)$ & $\begin{array}{l}\text { Managerial/ } \\
\text { normative }\end{array}$ & $\begin{array}{l}\text { Qual. analysis: } 13 \\
\text { multiunit } \\
\text { organizations in } \\
2005 \text { and } 2006\end{array}$ & $\begin{array}{l}\text { In a multiunit enterprise, four tiers of management constitute the field } \\
\text { organization store, district, regional, and divisional heads. All these } \\
\text { managers are responsible for meeting targets set by the CHQ and } \\
\text { implementing strategy. }\end{array}$ \\
\hline $\begin{array}{l}\text { Takeuchi, Shay, \& } \\
\text { Li (2008) }\end{array}$ & $(2-1)$ & $\begin{array}{l}\text { Cognitive } \\
\text { dissonance theory, } \\
\text { decision-making }\end{array}$ & $\begin{array}{l}\text { Quant.: survey } \\
\text { data; } 187 \\
\text { expatriates, } 24 \\
\text { CHQ executives }\end{array}$ & $\begin{array}{l}\text { Expatriate adjustment is influenced by the decision autonomy afforded to } \\
\text { expatriate managers; the relationship is moderated by a parent company's } \\
\text { operational experience with a particular foreign subsidiary. }\end{array}$ \\
\hline $\begin{array}{l}\text { Chen, Park, \& } \\
\text { Newburry (2009) }\end{array}$ & $(1 ; 2-1)$ & Control theory & $\begin{array}{l}\text { Quant.: survey of } \\
202 \text { manufacturing } \\
\text { IJVs in China } \\
(2002-03)\end{array}$ & $\begin{array}{l}\text { Hypothesizing that CHQ's usage of the control type is influenced by its } \\
\text { resource contributions, property-based contribution is linked with output } \\
\text { and process control, and knowledge-based contribution is related to process } \\
\text { and social control. }\end{array}$ \\
\hline $\begin{array}{l}\text { Lange, Boivie, \& } \\
\text { Henderson (2009) }\end{array}$ & $(1 ; 1-6(2))$ & $\begin{array}{l}\text { Innovation theory, } \\
\text { industry ecology }\end{array}$ & $\begin{array}{l}\text { Quant.: event } \\
\text { history analysis of } \\
\text { the US PC } \\
\text { industry, } 1975-94\end{array}$ & $\begin{array}{l}\text { Established firms diversifying into a new industry that owes its birth to a } \\
\text { disruptive technological change give birth to corporate children that are both } \\
\text { weaker survivors than freestanding start-ups and stronger legitimators of the } \\
\text { industry as a whole. }\end{array}$ \\
\hline $\begin{array}{l}\text { Law, Song, Wong, } \\
\text { \& Chen (2009) }\end{array}$ & $(2-1 ; 1-5(2))$ & $\begin{array}{l}\text { Resource- } \\
\text { dependence theory }\end{array}$ & $\begin{array}{l}\text { Quant.: Survey of } \\
229 \text { Chinese } \\
\text { subsidiaries of } \\
\text { foreign firms }\end{array}$ & $\begin{array}{l}\text { CHQ support and TMT commitment predict localization success (the extent } \\
\text { to which expatriate managers are replaced by local employees originally } \\
\text { held by expatriate managers). }\end{array}$ \\
\hline
\end{tabular}




\begin{tabular}{|c|c|c|c|c|}
\hline Author(s) (Year) & Focus & Theoretical Lens & Methodology & Key Findings related to the CHQ \\
\hline $\begin{array}{l}\text { Ambos, } \\
\text { Andersson, \& } \\
\text { Birkinshaw (2010) }\end{array}$ & $(2-1)$ & $\begin{array}{l}\text { Resource } \\
\text { dependence theory, } \\
\text { self-determination } \\
\text { theory }\end{array}$ & $\begin{array}{l}\text { Quant.: survey; } \\
257 \text { foreign-owned } \\
\text { subs. in AUS, } \\
\text { CAN, and the UK }\end{array}$ & $\begin{array}{l}\text { Subsidiaries are not able to increase their influence through initiatives } \\
\text { unless they get CHQs attention. Subsidiary initiatives have a direct effect on } \\
\text { subsidiary autonomy, but the caveat is that initiatives also evoke CHQ } \\
\text { monitoring, which in turn decreases the subsidiary's autonomy. }\end{array}$ \\
\hline $\begin{array}{l}\text { Ciabuschi, } \\
\text { Dellestrand, \& } \\
\text { Martín (2011a) }\end{array}$ & $(1-5(2))$ & $\begin{array}{l}\text { Business network } \\
\text { perspective }\end{array}$ & $\begin{array}{l}\text { Quant.: } 85 \\
\text { innovation projects } \\
\text { in } 23 \mathrm{MNCs}\end{array}$ & $\begin{array}{l}\text { CHQ involvement in the innovation development process improves BU } \\
\text { competencies while internal embeddedness does not. CHQ involvement, } \\
\text { driven by BU internal embeddedness, enhances the innovation impact on the } \\
\text { BU, which in turn influences innovation importance at corporate level. }\end{array}$ \\
\hline $\begin{array}{l}\text { Ciabuschi, } \\
\text { Forsgren, \& Martin } \\
\text { (2011b) }\end{array}$ & $(2-1 ; 1-5(2))$ & $\begin{array}{l}\text { international } \\
\text { business theory }\end{array}$ & \begin{tabular}{l|} 
Theory-building: \\
illustrative case of \\
Swedish firm and a \\
US subsidiary \\
\end{tabular} & $\begin{array}{l}\text { Two alternative approaches exist to explain the impact of CHQ involvement } \\
\text { on the innovation process performance of subsidiaries: (1) rationality } \\
\text { perspective, and (2) the sheer ignorance perspective. At the core of the latter } \\
\text { is the impossibility of the CHQ to assess ex ante what role to play. }\end{array}$ \\
\hline Crilly (2011) & $\begin{array}{l}(2-1 ; 2-1(3) ; 2- \\
1(4))\end{array}$ & Stakeholder theory & $\begin{array}{l}\text { Induction and } \\
\text { fuzzy-set analysis; } \\
52 \text { overseas } \\
\text { subsidiaries }\end{array}$ & $\begin{array}{l}\text { Internal control through the corporate parent can crowd out the voices of } \\
\text { local stakeholders. Further, some corporations are subject to scrutiny by } \\
\text { global stakeholders, and their subsidiaries face higher requirements for } \\
\text { social engagement than their peers do. }\end{array}$ \\
\hline $\begin{array}{l}\text { Semadeni \& } \\
\text { Cannella (2011) }\end{array}$ & $(1-2)$ & $\begin{array}{l}\text { Transaction cost } \\
\text { theory, agency } \\
\text { theory }\end{array}$ & $\begin{array}{l}\text { Quant. analysis; } \\
142 \text { spin-offs of } \\
\text { listed US firms; } \\
1986-97\end{array}$ & $\begin{array}{l}\text { While child firms benefit from some post spin-off links to the parent } \\
\text { (monitoring by CHQ executives), having too many links is negatively } \\
\text { related to performance. The findings suggest that there is a balance between } \\
\text { having too much CHQ involvement and not enough. }\end{array}$ \\
\hline $\begin{array}{l}\text { Alfoldi, Clegg, \& } \\
\text { McGaughey (2012) }\end{array}$ & $(1 ; 2-1)$ & $\begin{array}{l}\text { Contingency, } \\
\text { agency, } \\
\text { information- } \\
\text { processing theory }\end{array}$ & $\begin{array}{l}\text { Qual. analysis: } \\
\text { case study } \\
\text { (Unilever } \\
\text { Hungary); }\end{array}$ & $\begin{array}{l}\text { Delegating CHQ functions to local BUs offers benefits: (1) the ability to } \\
\text { balance integration and responsiveness at levels below the efficient scale for } \\
\text { RHQ; (2) the exploitation of local operational expertise on a regional level; } \\
\text { (3) relieving the CHQ of the burden of monitoring remote peripheral agents. }\end{array}$ \\
\hline $\begin{array}{l}\text { Baaij, Mom, Van } \\
\text { Den Bosch, \& } \\
\text { Volberda }(2012)\end{array}$ & $(1 ; 4-1)$ & $\begin{array}{l}\text { Managerial/ } \\
\text { normative (no } \\
\text { explicit theoretical } \\
\text { lens) }\end{array}$ & $\begin{array}{l}\text { Survey of } 58 \\
\text { Dutch MNCs; } \\
\text { illustrative cases }\end{array}$ & $\begin{array}{l}\text { The increasing internationalization of markets and industries is a driver for } \\
\text { the international relocation of elements of CHQ. Companies should assess } \\
\text { the strategic benefits and costs of relocation and consider using } \\
\text { communication technologies following the relocation. }\end{array}$ \\
\hline $\begin{array}{l}\text { Campbell, } \\
\text { Kunisch, \& } \\
\text { Müller-Stewens } \\
(2012)\end{array}$ & $(1 ; 3-1: 1-5)$ & $\begin{array}{l}\text { Managerial/ } \\
\text { normative } \\
\text { (parenting theory) }\end{array}$ & $\begin{array}{l}\text { Qual. analysis; } \\
\text { interviews with } 50 \\
\text { function heads at } \\
\text { European firms }\end{array}$ & $\begin{array}{l}\text { CHQ functional units should receive more guidance from chief executive } \\
\text { officers (CEOs) in order to contribute to corporate success; four ways can } \\
\text { help: (1) define major sources of value added, (2), review CHQ units } \\
\text { annually, (3) use corporate initiative matrix and (4) separate shared services. }\end{array}$ \\
\hline $\begin{array}{l}\text { Collis, Young, \& } \\
\text { Goold (2012) }\end{array}$ & $\begin{array}{l}(1 ; 3-1 ; 4-1 ; 1-5 ; 1- \\
6)\end{array}$ & $\begin{array}{l}\text { Organizational } \\
\text { contingency } \\
\text { theory, multiple } \\
\text { theoretical lenses }\end{array}$ & $\begin{array}{l}\text { Quant. analysis: } \\
\text { survey of } 250 \\
\text { MNC in } 6 \\
\text { countries; } 1997-99\end{array}$ & $\begin{array}{l}\text { MNC CHQ are more involved in "obligatory" and value creating and } \\
\text { control functions than in operational activities; the size of CHQ expands as } \\
\text { MNC geographic scope increases. Substantially different CHQ size of } \\
\text { MNCs from different countries indicates "administrative heritage". }\end{array}$ \\
\hline
\end{tabular}




\begin{tabular}{|c|c|c|c|c|}
\hline Author(s) (Year) & Focus & Theoretical Lens & Methodology & Key Findings related to the CHQ \\
\hline $\begin{array}{l}\text { Foss, Foss, \& Nell } \\
(2012)\end{array}$ & $(1 ; 2-1(3))$ & $\begin{array}{l}\text { International } \\
\text { business, } \\
\text { organizational } \\
\text { behavior }\end{array}$ & $\begin{array}{l}\text { Conceptual; } \\
\text { theory-building }\end{array}$ & $\begin{array}{l}\text { With respect to CHQ interventions, network MNCs should be particularly } \\
\text { careful to anticipate and take precautions against 'intervention hazards.' } \\
\text { Normative integration and procedural justice also serve to control harmful } \\
\text { CHQ intervention (and not just subsidiary opportunism). }\end{array}$ \\
\hline $\begin{array}{l}\text { Joseph \& Ocasio } \\
(2012)\end{array}$ & $(2-1 ; 1-5(2))$ & $\begin{array}{l}\text { Organization } \\
\text { design, multiple } \\
\text { lenses }\end{array}$ & $\begin{array}{l}\text { Qual.: inductive } \\
\text { analysis of GE's } \\
\text { governance system } \\
\text { from } 1951 \text { to } 2001 \\
\end{array}$ & $\begin{array}{l}\text { Collective vertical interactions between the CHQ and BUs happen through } \\
\text { cross-level channels; temporal coupling integrates levels and issues } \\
\text { simultaneously, yet focuses attention sequentially, providing more effective } \\
\text { conditions for joint attention and coordination between the CHQ and BU. }\end{array}$ \\
\hline $\begin{array}{l}\text { Laamanen, Simula, } \\
\text { \& Torstila (2012) }\end{array}$ & $(1 ; 3-1 ; 4-1)$ & $\begin{array}{l}\text { Economic/regional } \\
\text { development; } \\
\text { international } \\
\text { business }\end{array}$ & $\begin{array}{l}\text { Quant. analysis of } \\
52 \text { CHQ and RHQ } \\
\text { relocations in } \\
\text { Europe; } 1996-2006 \\
\end{array}$ & $\begin{array}{l}\text { There is an increasing trend toward CHQ/RHQ relocation. High taxes and a } \\
\text { high employment rate represent push factors that increase the likelihood of } \\
\text { relocation. Central location and low taxes represent pull factors that increase } \\
\text { the attractiveness of the HQ location. }\end{array}$ \\
\hline $\begin{array}{l}\text { Mahnke, Ambos, } \\
\text { Nell, \& Hobdari } \\
(2012)\end{array}$ & $(2-1 ; 1-5(2))$ & Decision-making & $\begin{array}{l}\text { Quant.: survey of } \\
42 \text { RHQ in } 5 \\
\text { countries }\end{array}$ & $\begin{array}{l}\text { RHQ can serve as an important additional source of knowledge and input, } \\
\text { and a bridge between local BUs and the CHQ. RHQ's autonomy and } \\
\text { signaling behavior have significant effects on its influence on corporate } \\
\text { strategy, and the RHQ's' charter moderates such bottom-up influence. }\end{array}$ \\
\hline $\begin{array}{l}\text { Tomassen, Benito, } \\
\text { \& Lunnan (2012) }\end{array}$ & $(2-1(3))$ & $\begin{array}{l}\text { Transaction cost } \\
\text { and internalization } \\
\text { theories }\end{array}$ & $\begin{array}{l}\text { Quant.: } 159 \text { MNC- } \\
\text { subsidiary } \\
\text { relationships; } \\
\text { Norway }\end{array}$ & $\begin{array}{l}\text { CHQ governance costs (ensuing establishment of subsidiaries abroad) are } \\
\text { driven by external contingencies as well as factors that characterize a } \\
\text { particular CHQ-subsidiary relationship. }\end{array}$ \\
\hline $\begin{array}{l}\text { Vahlne, Schweizer, } \\
\text { \& Johanson (2012) }\end{array}$ & $(1 ; 2-1)$ & Network theory & Conceptual & $\begin{array}{l}\text { The process of CHQ management to coordinate and manage the global firm } \\
\text { is characterized by uncertainty, which is due to a liability of outsidership } \\
\text { derived from the fact that CHQ is often not knowledgeable about the } \\
\text { networks and actions of its subsidiaries. }\end{array}$ \\
\hline $\begin{array}{l}\text { Kleinbaum \& } \\
\text { Stuart (2013) }\end{array}$ & (1) & Network theory & $\begin{array}{l}\text { Quant. case study } \\
\text { analysis: e-mail } \\
\text { analysis }\end{array}$ & $\begin{array}{l}\text { Corporate staff members have networks that are larger, more integrative, } \\
\text { and richer in structural holes mainly due to the sorting processes, rather than } \\
\text { the corporate tasks per se. Once people receive the 'corporate imprimatur,' } \\
\text { they retain aspects of it even when they move back to the line organization. }\end{array}$ \\
\hline $\begin{array}{l}\text { Nell \& Ambos } \\
(2013)\end{array}$ & $(1-2 ; 1-3 ; 1-6)$ & $\begin{array}{l}\text { Network theory } \\
\text { (embeddedness } \\
\text { perspective); } \\
\text { parenting theory }\end{array}$ & $\begin{array}{l}\text { Quant. analysis: } \\
\text { survey of } 124 \\
\text { subsidiaries in } \\
\text { Europe }\end{array}$ & $\begin{array}{l}\text { The external embeddedness of the MNC influences the CHQ' value } \\
\text { creation: The CHQ' investments into their own relationships with the } \\
\text { subsidiaries' contexts are positively related to the value added by the CHQ. } \\
\text { Tis relationship is stronger when the subsidiary itself is strongly embedded. }\end{array}$ \\
\hline
\end{tabular}

* The numbers in parentheses refer to Figure 1.

** To facilitate reading we replaced the different terms for CHQ found in the literature by $\mathrm{CHQ}$. BU = business unit; CHQ = corporate headquarters; IJV = international joint venture; $\mathrm{MBF}=$ multibusiness firm; $\mathrm{MNC}=$ multinational corporation; $\mathrm{RHQ}=$ regional headquarters. 